\title{
Review on the High-Temperature Thermophysical Properties of Continuous Casting Mold Fluxes for Highly Alloyed Steels
}

\section{Zhanjun $\mathrm{WANG}^{1)}$ and $I l$ SoHN ${ }^{1)^{*}}$}

1) Department of Materials Science and Engineering, Yonsei University

Abstract: Several recently developed highly alloyed steel grades have shown unsurpassed performance in terms of physical, chemical, and electromagnetic properties. However, broader commercialization of these steels has been hampered by limitations in mold flux performance. Newly developed steels containing considerable amounts of dissolved $\mathrm{Al}, \mathrm{Mn}$, and $\mathrm{Ti}$ actively react with typical $\mathrm{CaO}-\mathrm{SiO}_{2}$-based mold fluxes, which severely changes the composition and subsequently the thermophysical properties of the mold flux that determine the external and internal quality of the as-cast steels. These dynamic changes result in nonuniform heat transfer, lubrication issues, surface defects, and caster breakouts. This work critically assesses the current status of the high-temperature thermophysical properties of $\mathrm{CaO}-\mathrm{SiO}_{2}$-based and $\mathrm{CaO}-\mathrm{Al}_{2} \mathrm{O}_{3}$ based mold fluxes intended for use in casting highly alloyed steel grades. Thermophysical properties, including viscosity, crystallization, thermal conductivity, and heat flux, have been evaluated. The effect of compositional variables including $\mathrm{CaO} / \mathrm{SiO}_{2}, \mathrm{CaO} / \mathrm{Al}_{2} \mathrm{O}_{3}$, and $\mathrm{Al}_{2} \mathrm{O}_{3} / \mathrm{SiO}_{2}$ mass ratios and the additions of $\mathrm{CaF}_{2}, \mathrm{~B}_{2} \mathrm{O}_{3}, \mathrm{Li}_{2} \mathrm{O}, \mathrm{K}_{2} \mathrm{O}, \mathrm{Na}_{2} \mathrm{O}, \mathrm{TiO}_{2}$, and $\mathrm{BaO}$ on these high-temperature thermophysical properties are discussed.

Keywords: mold fluxes; thermophysical properties; viscosity; crystallization; thermal conductivity; heat transfer.

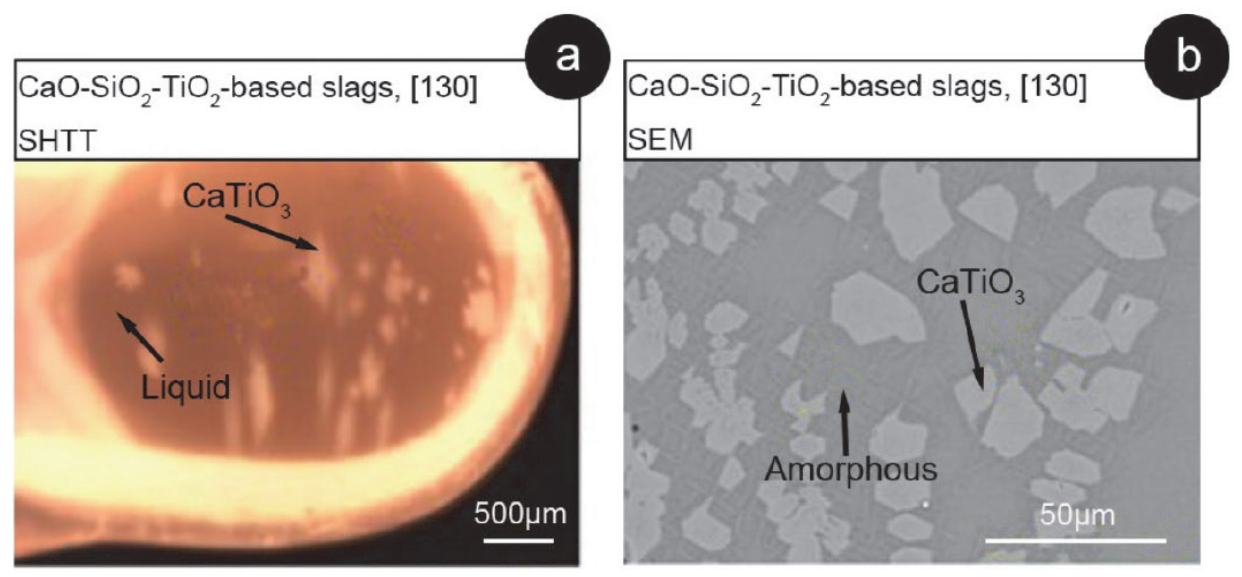




\title{
高合金鋼連続鋳造用モールドフラックスの 高温熱物性に関する総説
}

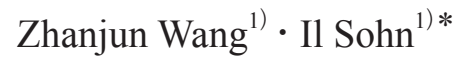 \\ Review on the High-Temperature Thermophysical Properties of Continuous Casting Mold Fluxes for Highly Alloyed Steels
} Zhanjun WANG and $I l$ SoHN

\section{1. 序論}

世界的に都市化が進み, 再生可能エネルギー, エネル ギー変換時のエネルギー損失低減, そして高燃費の輸送 の需要に伴い, 鋼鉄業では一般的な炭素鋼と比較して $\mathrm{Al}$, $\mathrm{Mn}$, およびTi濃度の高い高合金鋼の大幅な需要増加が見 られる ${ }^{1-6)}$ 。これらの次世代鋼は軽量化と高強度化かつ高 成形性能の両立, 高温耐腐食性, あるいは低ヒステリシス 損失を実現する高透磁率といった要求を満たすよう開発 されてきた ${ }^{7-9)}$ 。のような需要の高い鋼材の生産を高い 費用対効果で実現するためには連続鋳造工程が不可欠であ り，製品の内外の品質を担保する上ではモールドフラック スが重要な役割を果たす ${ }^{10-14)}$ 。最適なモールドフラックス は潤滑を高めるとともに, 水冷銅鋳型内で部分凝固シェル を通じて溶鋼から水平方向に一様な抜熱を行うために必要 な物理化学的特性を有するように設計されている ${ }^{7,15)}$ 。し かし，前述の鋼種や溶存する合金元素は，酸化還元反応の 熱力学的性質により，一般的な $\mathrm{CaO}-\mathrm{SiO}_{2}$ 系モールドフラッ クス成分と反応しうる ${ }^{16-19)}$ 。

Fig.1（a）では高 $\mathrm{Al}$ 鋼，高 $\mathrm{Mn}$ 鋼，高 $\mathrm{Al}$ 高 $\mathrm{Mn}$ 鋼，および 高 Ti鋼などの高合金鋼における引張強度と延性の関係を まとめている ${ }^{20)}$ 。 $1 \mathrm{wt} \%$ を超える $\mathrm{Al}$ を含む高 $\mathrm{Al}$ 変態誘起塑 性（TRIP）鋼は高い比強度と優れた延性を併せ持つため, 幅広い関心を集めている ${ }^{21)}$ 。しかし，連続鋳造中に生じる モールドフラックス中の $\mathrm{SiO}_{2}$ と鋼中に溶存した $\mathrm{A} 1$ の化学 反応によって, Fig.1 (b) に示すように $\mathrm{Al}_{2} \mathrm{O}_{3}$ と $\mathrm{SiO}_{2}$ の質量 濃度比 $\left(\mathrm{Al}_{2} \mathrm{O}_{3} / \mathrm{SiO}_{2}\right)$ を高め, 鋳造における諸問題を引き起 こし，半製品の品質の低下を招く ${ }^{22,23)}$ 。

最近, Mnが $10 \mathrm{wt} \%$ を超える商用化された高 $\mathrm{Mn}$ 双晶誘 起塑性 (TWIP) 鋼が TRIP鋼をさらに上回る強度や延性を 有することが明らかになり, 自動車産業や海運, 海上鋼構
造産業などの注目を集めている ${ }^{24)}$ 。Fig.1（c）に示している 通り，フラックスの $\mathrm{MnO}$ 濃度は鋼との接触時間が長くな るにつれて増加し, 比較的短時間で定常状態に達する傾向 がある ${ }^{25)}$ 。また, 延性の一様性の改善や遅れ破壊の抑制な どのさらなる機械特性の向上が $1 \mathrm{wt} \%$ を超える $\mathrm{Al}$ の添加 により実現できる ${ }^{17)}$ 。従来の $\mathrm{CaO}-\mathrm{SiO}_{2}$ 系モールドフラッ クスと高 $\mathrm{Mn}$ かつ高 $\mathrm{Al}$ の溶鋼の反応機構に注目した最近の 研究によると, Fig.1 (d) に示す通り, 鋼中 Al濃度はフラッ クスの最終組成と特性を決定する支配的な要因であり, 過 剩な $\mathrm{Al}_{2} \mathrm{O}_{3}$ 生成を至らしめることが示唆されている ${ }^{18,26)}$ 。

既存のケイ酸カルシウム系フラックスを用いた高 $\mathrm{Ti}$ フ ライト系ステンレス鋼の鋳造時には，モールドフラックス において $\mathrm{TiO}_{2}$ 濃度の増加が見られる。この現象は二次精錬 中に生成した溶鋼中の $\mathrm{TiO}_{2}$ や $\mathrm{TiN} 介$ 在物の吸収と, モール ドフラックス中の $\mathrm{SiO}_{2}$ による鋼中溶存 $\mathrm{Ti}$ の酸化によって 引き起こされている ${ }^{27)}$ 。溶存 $\mathrm{Ti}$ と $\mathrm{SiO}_{2}$ の反応は $\mathrm{Al}$ と $\mathrm{SiO}_{2}$ の反応ほど明白ではないものの, Fig.1 (e) に示される通り, かなりの量の $\mathrm{TiO}_{2}$ が見られる ${ }^{19)}$ 。このような $\mathrm{TiO}_{2}$ 濃度の増 加はモールドフラックスの熱物性も変化させる ${ }^{19,28)}$ 。

従来の $\mathrm{CaO}-\mathrm{SiO}_{2}$ 系モールドフラックスを用いた前述の 高合金鋼の鋳造中に扎いて想定されている理論的なスラグ 一メタル反応を Table 1 に示す。しかし, 精錬における実際 の製鋼スラグの反応と同様に, 複合酸化物を生成する反応 はまだ完全に理解されてはおらず，その解明は反応速度や モールドフラックスの熱物性を支配する熱力学的駆動力を 根本的に変える可能性を秘めている ${ }^{1,27,29)}$ 。

高 $\mathrm{Mn}$ 鋼や高 $\mathrm{Ti}$ 鋼に関しては，モールドフラックス中の $\mathrm{MnO}$ や $\mathrm{TiO}_{2}$ 濃度が増加し, それに対応して $\mathrm{SiO}_{2}$ 濃度は減 少する。高 $\mathrm{Al}$ 鋼の場合, 迅速に多量の $\mathrm{Al}_{2} \mathrm{O}_{3}$ が生成し, そ の結果 $\mathrm{SiO}_{2}$ の還元も見られ, 比較的短時間で定常状態に到 達する。製鋼温度において熱力学的に起こりうるこれらの

原著論文: ISIJ Int., Vol.60 (2020), No.12, pp.2705-2716, The diamond jubilee issue 掲載

2020年9月10日J-STAGE早期公開 (J-STAGE Advance published on Sep. 10, 2020) ; originally published in the diamond jubilee issue of ISIJ Int., Vol.60, 2020, No.12 ,pp.2705-2716 and the translated version was printed in Japanese with the author's permission under the supervision of Associate Editors, Prof. Hiroyuki Matsuura and Prof. Noritaka Saito.)

1) Department of Materials Science and Engineering, Yonsei University

(C) 2021 The Iron and Steel Institute of Japan. This is an open access article under the terms of the Creative Commons Attribution-NonCommercialNoDerivatives license (https://creativecommons.org/licenses/by-nc-nd/4.0/deed.ja). 
反応により，予め設計されたフラックスの熱物性を変える ほどのモールドフラックスの顕著な組成変化をもたらす ため, モールドフラックスの熱伝達能力や潤滑能力に影響 し，結果的に半製品の品質を低下させている。そのため, これらの反応を阻害または補償するため多大な努力が費や されてきた。

モールドフラックスの化学組成は鋳造操作中に絶えず 変化しているため, 凝固シェルと鋳型の間隙に入り込んだ モールドフラックスの性質は一貫しておらず，スラブ表面 における亀裂や凹みなどの品質に関する問題をもたらして いる。過小なモールドフラックス消費や過剩な焼結層の生 成などの鋳型内に打けるさらなる劣化条件も，ブレイクア ウト防止警報の発報による連続鋳造工程の中断を引き起こ す恐れがある ${ }^{1)}$ 。これらの現象はスラグ結晶化挙動や熱伝 達の一様性が現在の鋼種の製造条件を満たせていないこと により発生している。さらに，鋼種に関わらず，連続鋳造 工程に打いてはモールドフラックスの良好な潤滑性を担 保する必要がある。したがって, 様々な高合金鋼の鋳造に 関する参考や指針を提供する上で，開発されたモールドフ ラックスの特性を集約するために本総説をまとめた。

本総説では, 既存の文献において報告されている，高合
金鋼を対象に開発された $\mathrm{CaO}-\mathrm{SiO}_{2}$ 系および $\mathrm{CaO}-\mathrm{Al}_{2} \mathrm{O}_{3}$ 系 モールドフラックスの熱物性に関する結果に焦点を当てる ことを試みた。特に, モールドフラックスの粘度, 結晶化 挙動, 熱伝導率, および熱伝達挙動について評価した。様々 な添加成分や操業条件におけるモールドフラックスの特性 についての徹底した評価を通じて, 今後このような高合金 鋼の鋼種向けモールドフラックスの設計や最適化に向けた 技術的な指針や考えられる研究の方向性を明らかにするこ とができる。

Table 1. Theoretical and actual slag/metal reactions during casting of highly alloyed steels.

\begin{tabular}{cc}
\hline Theoretical reactions & Actual reactions \\
\hline$\left(\mathrm{SiO}_{2}\right)+[\mathrm{Al}] \rightarrow\left(\mathrm{Al}_{2} \mathrm{O}_{3}\right)+[\mathrm{Si}]$ & $3\left(\mathrm{SiO}_{2}\right)+4[\mathrm{Al}]+2(\mathrm{MgO})=$ \\
$\left(\mathrm{SiO}_{2}\right)+[\mathrm{Mn}] \rightarrow(\mathrm{MnO})+[\mathrm{Si}]$ & $2\left(\mathrm{SiO}_{2}\right)+2[\mathrm{Al}]+[\mathrm{Mn}]=2[\mathrm{Si}]+\mathrm{MnAl}_{2} \mathrm{O}_{4}$ \\
$\left(\mathrm{SiO}_{2}\right)+[\mathrm{Ti}] \rightarrow\left(\mathrm{TiO}_{2}\right)+[\mathrm{Si}]$ & $3\left(\mathrm{SiO}_{2}\right)+4[\mathrm{Al}]+(\mathrm{CaO})=[\mathrm{Si}]+\mathrm{CaAl}_{4} \mathrm{O}_{7}$ \\
$(\mathrm{MnO})+[\mathrm{Al}] \rightarrow\left(\mathrm{Al}_{2} \mathrm{O}_{3}\right)+[\mathrm{Mn}]$ & $\left(\mathrm{SiO}_{2}\right)+[\mathrm{Ti}]+(\mathrm{CaO})=[\mathrm{Si}]+\mathrm{CaTiO}_{3}$ \\
$\left(\mathrm{TiO}_{2}\right)+[\mathrm{Al}] \rightarrow\left(\mathrm{Al}_{2} \mathrm{O}_{3}\right)+[\mathrm{Ti}]$ & $2\left(\mathrm{SiO}_{2}\right)+[\mathrm{Ti}]+(\mathrm{CaO})=[\mathrm{Si}]+\mathrm{CaSiTiO}_{5}$ \\
{$[\mathrm{Ti}]+[\mathrm{N}] \rightarrow[\mathrm{TiN}]$} & $\left(\mathrm{TiO}_{2}\right)+[\mathrm{Al}]+(\mathrm{CaO})=[\mathrm{Ti}]+\mathrm{Ca}_{12} \mathrm{Al}_{14} \mathrm{O}_{33}$ \\
{$[\mathrm{TiN}]+\left(\mathrm{SiO}_{2}\right) \rightarrow[\mathrm{Si}]+\left(\mathrm{TiO}_{2}\right)+\mathrm{N}_{2}$} & {$[\mathrm{Ti}]+[\mathrm{N}]+\mathrm{C}=(\mathrm{TiC})+\mathrm{N}_{2}$} \\
$\ldots \ldots$ & $\ldots \ldots$
\end{tabular}
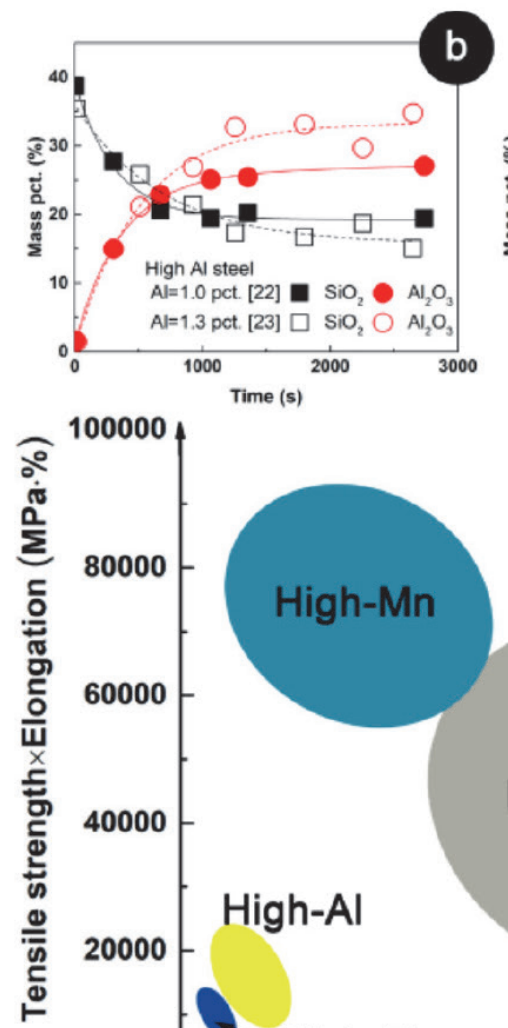
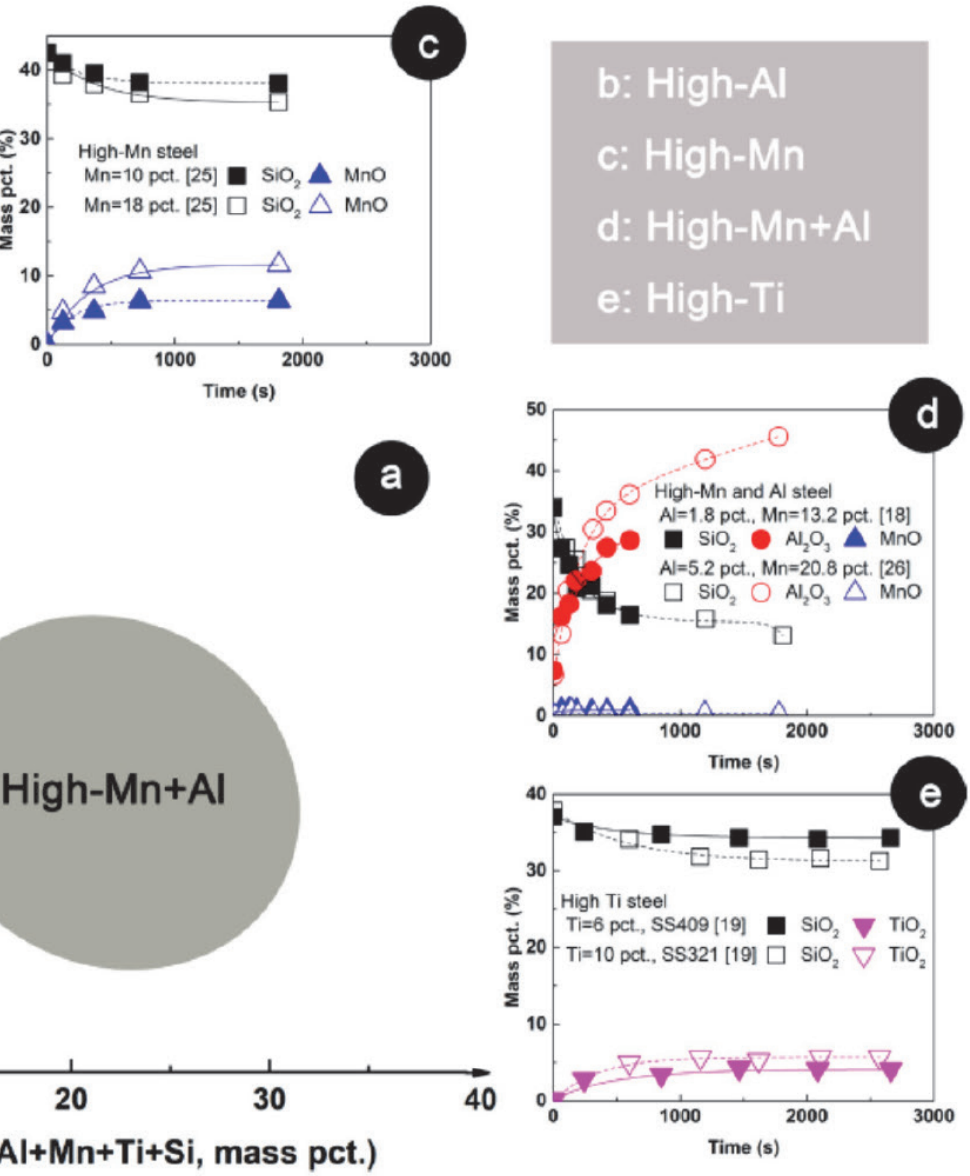

Fig. 1. (a) Tensile strength $\times$ elongation (MPa $\%$ ) characteristics of highly alloyed steels and the compositional evolution in molten fluxes for (b) high-Al steels, (c) high-Mn steels, (d) high-Mn and high-Al steels, and (e) high-Ti steels. Adapted from published literature. ${ }^{18-20,22,23,25,26)}$ (Online version in color.) 


\section{2. モールドフラックスの開発に関する分類と傾向}

Table 2 に炭素鋼用の従来の多成分系モールドフラック スに打りる一般的な化学組成を示している ${ }^{30)}$ 。従来のモ一 ルドフラックスはいくつかのフラックス材を組み合わせ て添加することでモールドフラックスの熱物性を最適化 し安定した連続鋳造を担保できる $\mathrm{CaO}-\mathrm{SiO}_{2}$ スラグ系が基 本である。これらのフラックス材のうち，フッ化物（通常 は $\left.\mathrm{CaF}_{2}\right)$ は，核生成を伴う初期結晶化温度を高めつつ液 相線温度や粘度を下げモールドフラックスの流動性を向 上することができるため, 添加剤として一般的に用いら れている ${ }^{31,32)}$ 。結晶化温度が上昇するにつれて, Cuspidine $\left(\mathrm{Ca}_{4} \mathrm{Si}_{2} \mathrm{O}_{7} \mathrm{~F}_{2}\right)$ の一次結晶相が容易に生成して一様に分散し, 溶鋼と水冷銅鋳型の間における水平方向の熱伝達を効果的 に制御するために用いられる。

一方で，過剩なフッ素濃度は環境にとって有害な HF， $\mathrm{SiF}_{4}$ および $\mathrm{NaF}$ 生成し，連続鋳造機の腐食を悪化させ る ${ }^{33-35)}$ 。一般的な鋳造操業中に扎て，モールドフラック ス中の最大 $30 \mathrm{wt} \%$ までのフッ化物は二次冷却排水に溶け 込むと推定されており, 水の污染や機器の腐食を悪化させ ている ${ }^{36)}$ 。環境調和型治金プロセスの出現を踏まえ，鋼材 品質を維持または向上させながら低フッ素またはフッ素を 含まないモールドフラックスを開発する動きが活発化して いる。また，フッ化物含有量を減らすことによるモールド フラックスの特性への悪影響を補償するため, $\mathrm{Na}_{2} \mathrm{O}, \mathrm{K}_{2} \mathrm{O}$, $\mathrm{Li}_{2} \mathrm{O}, \mathrm{MgO}, \mathrm{MnO}, \mathrm{B}_{2} \mathrm{O}_{3}$, および $\mathrm{TiO}_{2}$ などの酸化物も多成 分系モールドフラックスに添加されており, ホウケイ酸 カルシウム $\left(\mathrm{Ca}_{11} \mathrm{Si}_{4} \mathrm{~B}_{2} \mathrm{O}_{22}\right)$ や Perovskite $\left(\mathrm{CaTiO}_{3}\right)$ の一次結 晶相が $\mathrm{CaO}-\mathrm{SiO}_{2}$ 系モールドフラックスにおける一般的な Cuspidine相の代替として用いられている ${ }^{37-40) 。 ~}$

近年開発された高合金鋼や顧客の期待の向上, 環境調和 型プロセスのニーズの増加により，モールドフラックスの 要件や組成が大きく変化してきた。スラグと溶鋼中成分間 の著しい反応がこのような特殊鋼の場合においてよく見 られ，顕著な組成変化に至っている。特に，高 $\mathrm{SiO}_{2}$ 組成か ら高 $\mathrm{Al}_{2} \mathrm{O}_{3}$, 高 $\mathrm{TiO}_{2}$, あるいは高 $\mathrm{MnO}$ 組成へのモールドフ ラックス組成変化が見られる。いくつかの研究において非 反応性の $\mathrm{CaO}-\mathrm{Al}_{2} \mathrm{O}_{3}$ 系または $\mathrm{CaO}-\mathrm{TiO}_{2}$ 系モールドフラッ クスの開発を試みているが，結晶化や熱伝達，およびその 後の潤滑に対する悪影響の制御における問題が生じ，熱物 性に対する悪影響を補償するため $\mathrm{B}_{2} \mathrm{O}_{3}, \mathrm{Li}_{2} \mathrm{O}, \mathrm{Na}_{2} \mathrm{O}$ および
$\mathrm{BaO}$ などの添加剤が多量に必要となっている ${ }^{15,41-44)}$

モールドフラックス内に扎てて，各成分はそれぞれの アニオンやカチオンへと解離し，相互作用して配位結合を 形成し，短範囲規則性構造単位をもたらしている。フラッ クスを構成しているこれらの成分はネットワーク形成成 分 $\left(\mathrm{SiO}_{2}, \mathrm{~B}_{2} \mathrm{O}_{3}, \mathrm{TiO}_{2}, \mathrm{Fe}_{2} \mathrm{O}_{3}\right.$ など) やネットワーク修飾成分 $\left(\mathrm{CaO}, \mathrm{BaO}, \mathrm{FeO}, \mathrm{Na}_{2} \mathrm{O}, \mathrm{Li}_{2} \mathrm{O}\right.$ など $)$ として機能する ${ }^{11,45,46)}$ 。 $\mathrm{Al}_{2} \mathrm{O}_{3}$ は存在している既存のネットワーク形成成分酸化物 と修飾成分酸化物の全体的な割合に応じてネットワーク 形成成分としても修飾成分としても働く両性酸化物であ る $^{47,48)}$ 。ネットワークを形成あるいは修飾するカチオンや アニオンの間における相互作用を通じて形成される構造単 位はスラグの粘度や結晶化挙動と相関しており, 結果とし てフラックスの潤滑および熱伝達挙動や半製品の表面品質 にも影響する。一般的なモールドフラックスの粘度, 結晶 化温度, 熱伝導率, および熱フラックスに対する一般的な 影響を Table 3 にまとめている ${ }^{28,32,39,42,49-84)}$ 。

\section{3. 様々な高合金鋼における モールドフラックスの挙動}

\section{$3 \cdot 1$ 高 $\mathrm{Al}$ 鋼におけるフラックスの開発}

\section{$3 \cdot 1 \cdot 1$ 粘性挙動}

高 $\mathrm{Al}$ 鋼用モールドフラックスの設計には主に 2 つアアプ ローチがある。そのひとつは $\mathrm{CaO}-\mathrm{SiO}_{2}$ 系スラグの特性維 持に基づいており, 異なるフラックス材を添加することで 必要なモールドフラックスの特性を確保する。高 $\mathrm{A} 1$ 鋼の鋳 造中に発生するスラグー溶鋼間反応における熱力学的平衡 状態から予想される組成変化を推定することで, 適切なフ ラックス材の追加により許容可能な潤滑や熱伝達に必要な 熱物性を実現できる。もう1つのアプローチは溶存 $\mathrm{Al}$ と反 応しない $\mathrm{CaO}-\mathrm{Al}_{2} \mathrm{O}_{3}$ 系スラグの開発に基づいており，様々 なフラックス材を添加することで既存のモールドフラック スと同等の熱物性を実現しつつCuspidine相以外の異なる 一次結晶相を実現できる ${ }^{85)}$

Blazek ${ }^{86)}$ と Kim ${ }^{18)}$ は高 $\mathrm{Al}$ 鋼の鋳造における $\mathrm{CaO}-$ $\mathrm{SiO}_{2}$ 系モールドフラックスの活用を研究し, スラグ中 $\mathrm{SiO}_{2}$ 濃度が許容值以上の場合, 溶融フラックスプール中の

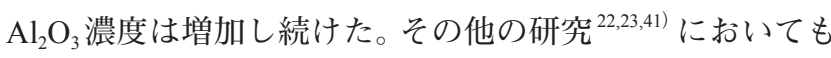
この傾向が見られ，経験的な証拠によると，その許容 $\mathrm{SiO}_{2}$ 濃度は約 $10 \mathrm{wt} \%$ であるように思われる。フラックスの融

Table 2. Compositions of traditional mold flux and some typical newly developed mold fluxes for some special alloy steels.

\begin{tabular}{|c|c|c|c|c|c|c|c|c|c|c|c|c|c|c|}
\hline Mold flux classification & $\mathrm{CaO}$ & $\mathrm{SiO}_{2}$ & $\mathrm{Al}_{2} \mathrm{O}_{3}$ & $\mathrm{Na}_{2} \mathrm{O}$ & $\mathrm{K}_{2} \mathrm{O}$ & $\mathrm{MgO}$ & $\mathrm{MnO}$ & $\mathrm{Fe}_{2} \mathrm{O}_{3}$ & $\mathrm{~F}$ & $\mathrm{Li}_{2} \mathrm{O}$ & $\mathrm{B}_{2} \mathrm{O}_{3}$ & $\mathrm{BaO}$ & $\mathrm{ZrO}_{2}$ & $\mathrm{TiO}_{2}$ \\
\hline Conventional mold flux & $22-45$ & $17-56$ & $0-13$ & $0-25$ & $0-2$ & $0-10$ & $0-5$ & $0-6$ & $2-15$ & $0-5$ & $0-19$ & $0-10$ & - & - \\
\hline Mold flux for high-Al steel & $19-46$ & $9-42$ & $1.5-46$ & $9-13$ & - & $0-2$ & - & - & $0-15$ & $0-7$ & $0-17$ & $0-10$ & $0-5$ & - \\
\hline Mold flux for high-Mn steel & $17-42$ & $5-54$ & $0-49$ & $0-14$ & - & $0-15$ & $3-14$ & $0-2$ & $0-20$ & $0-1$ & $0-25$ & - & - & - \\
\hline Mold flux for high-Ti steel & $27-43$ & $28-43$ & $2-7$ & $4-23$ & - & $0-4$ & $0-3$ & - & $0-17$ & $0-2$ & $2-6$ & - & - & $0-30$ \\
\hline
\end{tabular}


点を下げる必要があることを考慮すると，最大 $10 \mathrm{wt} \%$ ま での $\mathrm{SiO}_{2}$ の添加は可能であると考えられる。より高い $\mathrm{CaO}$ と $\mathrm{SiO}_{2}$ の質量濃度比 $\left(\mathrm{CaO} / \mathrm{SiO}_{2}\right)$ でより低い粘度と融点を 有する $\mathrm{CaO}-\mathrm{SiO}_{2}$ 系モールドフラックスでは溶鋼ースラグ 間反応を抑え反応の熱力学的駆動力を下げることができ る ${ }^{23)}$ 。 $\mathrm{Al}$ と $\mathrm{SiO}_{2}$ の間における酸化還元反応をふまえ, 複数 の研究で $\mathrm{Al}_{2} \mathrm{O}_{3}$ と $\mathrm{SiO}_{2}$ の質量濃度比 $\left(\mathrm{Al}_{2} \mathrm{O}_{3} / \mathrm{SiO}_{2}\right)$ が $\mathrm{CaO}-$ $\mathrm{Al}_{2} \mathrm{O}_{3}-\mathrm{SiO}_{2}$ 系スラグの熱物性值に与える影響に注目してい る。様々なスラグ系に打いてモールドフラックスの $\mathrm{Al}_{2} \mathrm{O}_{3} /$ $\mathrm{SiO}_{2}$ 比と粘度の関係を Fig.2 (a) に示している。Liao ら ${ }^{87)}$ は $\mathrm{Al}_{2} \mathrm{O}_{3} / \mathrm{SiO}_{2}$ 比が 0.11 から 0.56 の範囲で増加することにより $\mathrm{CaO}-\mathrm{SiO}_{2}-\mathrm{Al}_{2} \mathrm{O}_{3}-\mathrm{MgO}$ 系スラグの粘度が僅かに低下するこ とを見出した。対照的に, $\mathrm{Li} ら^{53)}$ と $\mathrm{Yu} ら^{57)}$ は $\mathrm{CaO}-\mathrm{SiO}_{2}-$ $\mathrm{Al}_{2} \mathrm{O}_{3}-\mathrm{CaF}_{2}$ 系 と $\mathrm{CaO}-\mathrm{SiO}_{2}-\mathrm{Al}_{2} \mathrm{O}_{3}-\mathrm{CaF}_{2}-\mathrm{MgO}-\mathrm{Na}_{2} \mathrm{O}-\mathrm{MnO}-$ $\mathrm{Li}_{2} \mathrm{O}$ 系スラグに扔いて, $\mathrm{Al}_{2} \mathrm{O}_{3} / \mathrm{SiO}_{2}$ 比の増加に応じて粘度 は最初に低下するもののその後上昇する複雑な挙動を見出 した。しかし, Zhang ら ${ }^{88)}$ は $\mathrm{CaO}-\mathrm{SiO}_{2}-\mathrm{Al}_{2} \mathrm{O}_{3}-\mathrm{CaF}_{2}$ 系モール ドフラックス系において $\mathrm{Al}_{2} \mathrm{O}_{3} / \mathrm{SiO}_{2}$ 比が 0.06 から 0.57 まで の範囲で増加するにつれて粘度も上昇することを観察し, Zhang ${ }^{89)}$ が報告している $\mathrm{CaO}-\mathrm{SiO}_{2}-\mathrm{Al}_{2} \mathrm{O}_{3}-\mathrm{CaF}_{2}$ スラグに おいて $\mathrm{Al}_{2} \mathrm{O}_{3} / \mathrm{SiO}_{2}$ 比を 0.14 から 0.46 まで変化させたことに よる結果と同程度であった。異なる $\mathrm{Al}_{2} \mathrm{O}_{3} / \mathrm{SiO}_{2}$ 比に打ける
粘度の相違は3つの競合的な要因によって説明できる ${ }^{53,57) 。 ~}$ まず, $\mathrm{Al}_{2} \mathrm{O}_{3}$ の両性的挙動によりネットワークを形成する $\left[\mathrm{AlO}_{4}\right]^{5-}$ 四面体構造単位またはネットワークを修飾する

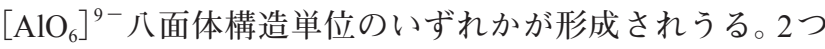
目に，新たに形成された $\left[\mathrm{AlO}_{4}\right]$-四面体構造単位が存在す る高 $\mathrm{Al}_{2} \mathrm{O}_{3}$ 濃度の場合に, より多くの $\mathrm{Ca}^{2+}$ イオンが電荷補 償カチオンとして作用する必要がある。この現象はネット ワークを修飾する $\mathrm{Ca}^{2+}$ イオンの量を減らし, 電気的中性を 満足するために非架橋酸素 $\left(\mathrm{O}^{-}\right)$から架橋酸素 $\left(\mathrm{O}^{\circ}\right)$ への 変換が促進される。その結果，より多くの $\mathrm{O}^{\circ}$ がネットワー ク構造の重合を進めて粘度の上昇につながる。3つ目に, 強い $\mathrm{Si}-\mathrm{O}$ 結合 (結合長 $1.61 \times 10^{-10} \mathrm{~m}$ ) が弱い Al-O 結合 (結 合長 $\left.1.75 \times 10^{-10} \mathrm{~m}\right)$ に置き換わることでネットワーク構 造が弱まり溶融せん断に必要な力が小さくなる ${ }^{55,90)}$ 。その ため, $\mathrm{Al}_{2} \mathrm{O}_{3}$ 濃度の初期の増加は粘度を低下させる $\mathrm{Al}-\mathrm{O}$ 結 合および $\mathrm{Si}-\mathrm{O}$ 結合の特性に依存している傾向にあり，さ らなる $\mathrm{Al}_{2} \mathrm{O}_{3}$ の添加は $\left[\mathrm{AlO}_{4}\right]$ - 四面体構造を有する複雑な 構造を形成して $\mathrm{O}^{\circ}$ 生成を促進し粘度を高める傾向にある。 モールドフラックスを構成するこれらの要因や成分を踏ま えると，両性 $\mathrm{Al}_{2} \mathrm{O}_{3}$ はスラグ系によって挙動が変化しうる。

$\mathrm{Kim}$ and $\mathrm{Sohn}^{52)}$ はTRIP鋼への応用のため $\mathrm{Na}_{2} \mathrm{O}$ を含む $\mathrm{CaO}-\mathrm{SiO}_{2}$ 系モールドフラックスの粘度に対する $\mathrm{CaF}_{2}$ の影

Table 3. Viscosity, crystallization temperature, thermal conductivity and heat flux of some typical $\mathrm{CaO}-\mathrm{SiO}_{2}-\mathrm{based}$ and $\mathrm{CaO}_{-} \mathrm{Al}_{2} \mathrm{O}_{3}$ -

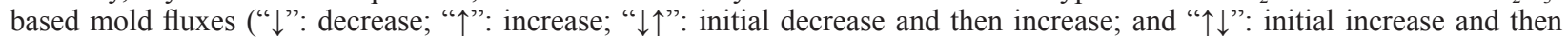
decrease).

\begin{tabular}{|c|c|c|c|c|c|c|c|c|c|c|c|c|c|c|c|}
\hline $\begin{array}{c}\text { Thermophysical } \\
\text { properties }\end{array}$ & Slag system & $\mathrm{C} / \mathrm{S}$ & $\mathrm{C} / \mathrm{A}$ & $\mathrm{A} / \mathrm{S}$ & $\mathrm{Al}_{2} \mathrm{O}_{3}$ & $\mathrm{CaF}_{2}$ & $\mathrm{Na}_{2} \mathrm{O}$ & $\mathrm{K}_{2} \mathrm{O}$ & $\mathrm{MgO}$ & $\mathrm{MnO}$ & $\mathrm{B}_{2} \mathrm{O}_{3}$ & $\mathrm{Li}_{2} \mathrm{O}$ & $\mathrm{TiO}_{2}$ & $\mathrm{BaO}$ & Reference \\
\hline \multirow{2}{*}{ Viscosity } & $\mathrm{CaO}-\mathrm{SiO}_{2}$-based mold flux & \multirow[t]{2}{*}{$\downarrow$} & & & & $\downarrow$ & $\downarrow$ & $\downarrow$ & $\downarrow$ & $\downarrow$ & $\downarrow$ & $\downarrow$ & $\uparrow$ & $\downarrow$ & \multirow{2}{*}{$28,39,42,50-59)$} \\
\hline & $\mathrm{CaO}-\mathrm{Al}_{2} \mathrm{O}_{3}$-based mold flux & & $\downarrow \uparrow$ & $\downarrow \uparrow$ & & $\downarrow$ & $\downarrow$ & $\downarrow$ & $\downarrow$ & $\downarrow$ & $\downarrow$ & $\downarrow$ & $\uparrow$ & & \\
\hline \multirow{2}{*}{$\begin{array}{l}\text { Crystallization } \\
\text { temperature }\end{array}$} & $\mathrm{CaO}-\mathrm{SiO}_{2}$-based mold flux & \multirow[t]{2}{*}{$\uparrow \uparrow$} & & & $\uparrow$ & $\uparrow$ & $\uparrow$ & $\downarrow$ & & $\downarrow$ & $\downarrow$ & $\uparrow$ & $\downarrow$ & $\uparrow$ & \multirow{2}{*}{$32,60-70)$} \\
\hline & $\mathrm{CaO}-\mathrm{Al}_{2} \mathrm{O}_{3}$-based mold flux & & $\downarrow \uparrow$ & $\uparrow$ & & $\downarrow$ & $\downarrow \uparrow$ & & & $\downarrow$ & $\downarrow$ & $\uparrow$ & $\downarrow$ & & \\
\hline $\begin{array}{c}\text { Thermal } \\
\text { conductivity }\end{array}$ & $\mathrm{CaO}-\mathrm{SiO}_{2}$-based mold flux & $\uparrow$ & & $\downarrow$ & $\downarrow$ & $\downarrow$ & $\downarrow$ & & & & & & $\uparrow$ & $\uparrow$ & $66,71-78)$ \\
\hline \multirow{2}{*}{ Heat flux } & $\mathrm{CaO}-\mathrm{SiO}_{2}$-based mold flux & \multirow[t]{2}{*}{$\downarrow$} & & $\uparrow$ & & $\downarrow$ & $\downarrow$ & & & $\uparrow$ & & $\downarrow$ & $\uparrow$ & $\downarrow$ & \multirow{2}{*}{$66,75-84)$} \\
\hline & $\mathrm{CaO}-\mathrm{Al}_{2} \mathrm{O}_{3}$-based mold flux & & $\uparrow \downarrow$ & $\downarrow \uparrow$ & & $\uparrow$ & $\uparrow$ & & & $\uparrow$ & $\downarrow$ & & $\uparrow$ & & \\
\hline
\end{tabular}

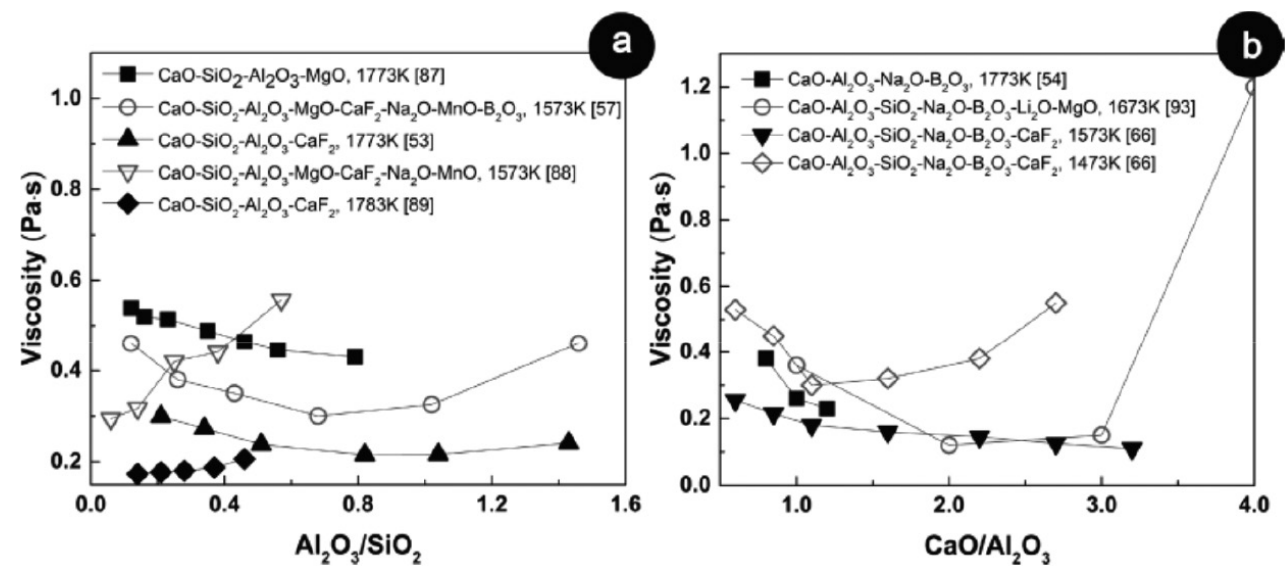

Fig. 2. (a) Viscosity of $\mathrm{CaO}-\mathrm{SiO}_{2}$-based mold fluxes with different $\mathrm{Al}_{2} \mathrm{O}_{3} / \mathrm{SiO}_{2}$ ratios and (b) viscosity of $\mathrm{CaO}-\mathrm{Al}_{2} \mathrm{O}_{3}$-based mold fluxes with different $\mathrm{CaO} / \mathrm{Al}_{2} \mathrm{O}_{3}$ ratios. Adapted from published literature. ${ }^{53,54,57,66,87-89,93)}$ 
響を調べた。 $\mathrm{CaF}_{2}$ を最大 $8 \mathrm{wt} \%$ まで添加することで粘度が 低下したが, $8 \mathrm{wt} \%$ 以上ではさらなる効果は見られなかっ た。 $\mathrm{CaF}_{2}$ と $\mathrm{NaF}$ はスラグネットワークの解離反応におい て同様の効果を有し, 粘度を下げるとともに冷却中の初 晶Cuspidine相の形成を加速するための拡散の速度を改善 する。しかし, $\mathrm{CaF}_{2}$ や $\mathrm{NaF}$ と $\mathrm{SiO}_{2}$ との反応や高温における フッ化物の揮発により，鋳造機において検討すべき新たな 操業上の課題が発生する可能性がある ${ }^{32)}$ 。

フッ化物に関する懸念の一部を回避するため, 一部の研 究では高 $\mathrm{Al}$ 系 TRIP鋼用に $\mathrm{B}_{2} \mathrm{O}_{3}$ と $\mathrm{Li}_{2} \mathrm{O}$ を含む低フッ素あ るいはフッ素フリーの $\mathrm{CaO}-\mathrm{SiO}_{2}$ 系モールドフラックスの 開発に注目している ${ }^{28,52,57)}$ 。ネットワーク形成成分である $\mathrm{B}_{2} \mathrm{O}_{3}$ とネットワーク修飾成分である $\mathrm{Li}_{2} \mathrm{O}$ は両方とも粘度 を低下させることができるが，その役割は異なる。 $\left[\mathrm{BO}_{4}\right]$ - 四面体構造単位は最初に形成されるものの, B-O 結合は $\mathrm{Si}-\mathrm{O}$ 結合よりも結合エネルギーが低いため高温では $\mathrm{B}-\mathrm{O}$ 結合が容易に切断され，不安定な $\left[\mathrm{BO}_{4}\right]$ - 四面体構造単位 からより構造の緩やかな $\left[\mathrm{BO}_{3}\right]$-三角形構造単位への变化 が促進されるため，スラグ構造が単純化して粘度が低くな る。極めて塩基性の酸化物である $\mathrm{Li}_{2} \mathrm{O}$ はネットワーク構 造を切断し粘度を低下させる遊離酸化物イオン $\left(\mathrm{O}^{2-}\right)$ を 供給できるが， $\mathrm{Li}_{2} \mathrm{O}$ 濃度が $2 \mathrm{wt} \%$ 以上の場合，あるいはフ ラックス材である $\mathrm{Na}_{2} \mathrm{O}$ と $\mathrm{CaF}_{2}$ がすでに十分にフラックス 系に含まれる場合にはその効果は限定的である。モールド フラックスへの $\mathrm{Na}_{2} \mathrm{O}$ の添加は一般的に粘度を低下させ, その添加効果は融体内に複雑な構造単位が十分に存在して いる場合により顕著である ${ }^{91)}$ 。しかし, $\mathrm{B}_{2} \mathrm{O}_{3}$ と $\mathrm{Na}_{2} \mathrm{O}$ の両 方を含む $\mathrm{CaO}-\mathrm{SiO}_{2}$ 系フラックスでは $\mathrm{NaBO}_{2}$ 気体の著しい 揮発が観察されるため, 揮発を最小限に抑えるために厚い パウダー層が必要となる ${ }^{92)}$ 。前述の研究より, $\mathrm{CaO}-\mathrm{SiO}_{2}$ 系 フラックスの開発については様々なフラックス材の添加 による組成変化を補うことに集中し，それによる熱物性へ の影響に注目している。これらの研究においては $\mathrm{Al}$ と $\mathrm{SiO}_{2}$ の反応は不可避であると仮定されており, 動的な組成変化 を検討している。

別のアプローチとして, 非反応性 $\mathrm{CaO}-\mathrm{Al}_{2} \mathrm{O}_{3}$ 系モールド フラックスの開発が挙げられる ${ }^{42)}$ 。 Kim and $\mathrm{Sohn}^{54)}$ は $\mathrm{CaO}-$ $\mathrm{Al}_{2} \mathrm{O}_{3}-\mathrm{Na}_{2} \mathrm{O}-\mathrm{B}_{2} \mathrm{O}_{3}$ 系の粘度を調べ, Fig.2（b）に示す通り， $\mathrm{B}_{2} \mathrm{O}_{3}$ 濃度が 8-18 wt\% の場合に打いて $\mathrm{CaO} / \mathrm{Al}_{2} \mathrm{O}_{3}$ 質量濃度比 $\left(\mathrm{CaO} / \mathrm{Al}_{2} \mathrm{O}_{3}\right)$ が 0.8 から 1.1 へ増加するにつれて粘度が低下 することを明らかにした。しかし， $\mathrm{CaO} / \mathrm{Al}_{2} \mathrm{O}_{3}$ 比が 2 以上ま で増加し続けると, 固体 $\mathrm{CaO}$ の影響により粘度が上昇し始 めた ${ }^{93)}$ 。 $\mathrm{CaO} / \mathrm{Al}_{2} \mathrm{O}_{3}$ 比の増加による類似の粘度の $\mathrm{V}$ 字型の 変化は, 比較的低い温度における $\mathrm{CaO}-\mathrm{Al}_{2} \mathrm{O}_{3}-\mathrm{SiO}_{2}-\mathrm{Na}_{2} \mathrm{O}-$ $\mathrm{B}_{2} \mathrm{O}_{3}-\mathrm{CaF}_{2}$ スラグ系で $\mathrm{Yan}$ ら $^{66)}$ によって報告されている。 粘度のこのような変化はより高い温度での融体のネット ワーク構造に密接に関連しており, スラグの $\mathrm{CaO} / \mathrm{Al}_{2} \mathrm{O}_{3}$ 比 の増加につれて重合度 (DOP) が低下する。結晶化温度は
$\mathrm{CaO} / \mathrm{Al}_{2} \mathrm{O}_{3}$ 比の増加と共に上昇するため結晶は $\mathrm{CaO} / \mathrm{Al}_{2} \mathrm{O}_{3}$ 比が高くなるほどより速やかに晶出し, 冷却が進むと結晶 の成長も促進され，結果として粘度も上昇する。

$\mathrm{B}_{2} \mathrm{O}_{3}$ 濃度の増加と共に $\mathrm{CaO}-\mathrm{Al}_{2} \mathrm{O}_{3}$ 系モールドフラックス の粘度は低下し, これは $\mathrm{CaO}-\mathrm{SiO}_{2}$ 系モールドフラックス の挙動と似ている ${ }^{54,56)}$ 。構造解析によると, $\mathrm{B}_{2} \mathrm{O}_{3}$ 濃度の増 加によって不安定な $\left[\mathrm{BO}_{4}\right]$ - 四面体構造単位の分解を伴い ながら $\left[\mathrm{BO}_{3}\right]$-三角形構造単位中の B-O 結合の構築が促さ れ, その結果, スラグ構造において $\left[\mathrm{BO}_{3}\right]$-三角形構造単 位が主要単位となる。そのため, $\left[\mathrm{BO}_{3}\right]$-三角形構造単位と $\left[\mathrm{AlO}_{4}\right]$ - 四面体構造単位の間における結合が促されて 3 次 元構造から部分的な 2 次元構造へとネットワーク構造が変 化し，それにより構造が弛緩して粘度の低下をもたらして

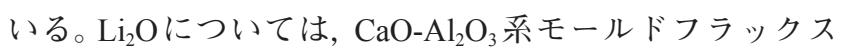
の粘度は $\mathrm{CaO}$ を $\mathrm{Li}_{2} \mathrm{O}$ で置換することにより低下する傾向 にあった ${ }^{94)}$ 。 $\mathrm{Li}_{2} \mathrm{O}$ はイオン性融体においてその成分である カチオンとアニオンへ解離するため, $\mathrm{O}^{2-}$ が $\mathrm{Al}-\mathrm{O}$ 共有結合 を切断し粘度を低下させることができる ${ }^{95)}$ 。しかし, $\mathrm{Li}_{2} \mathrm{O}$ 濃度が $7 \mathrm{wt} \%$ を超えると, 高融点のアルミン酸リチウム $\left(\mathrm{LiAlO}_{2}\right)$ 結晶相の生成により粘度が僅かに上昇する ${ }^{94)}$ 。

Wang and $\mathrm{Sohn}^{55)}$ によると, $\mathrm{CaO}$ を同量の $\mathrm{BaO}$ で置換す ると $\mathrm{CaO}-\mathrm{BaO}-\mathrm{SiO}_{2}-\mathrm{Al}_{2} \mathrm{O}_{3}-\mathrm{MgO}$ スラグの粘度が上昇し, $\mathrm{CaO}-\mathrm{SiO}_{2}-\mathrm{Al}_{2} \mathrm{O}_{3}-\mathrm{BaO}$ スラグ系 ${ }^{95)}$ や $\mathrm{CaO}-\mathrm{SiO}_{2}-\mathrm{Al}_{2} \mathrm{O}_{3}-\mathrm{MgO}-$ $\mathrm{Na}_{2} \mathrm{O}-\mathrm{Li}_{2} \mathrm{O}-\mathrm{CaF}_{2}-\mathrm{BaO}$ スラグ系 ${ }^{58)}$ に関する他の研究で観察 されている傾向と一致している。特に $\mathrm{BaO}$ 濃度が高くなる と粘度は上昇する傾向を示し，これは $\mathrm{BaO}(153.33 \mathrm{~g} / \mathrm{mol})$ と $\mathrm{CaO}(56.08 \mathrm{~g} / \mathrm{mol})$ の間の顕著な式量の違いによってネッ トワーク修飾成分の数が劇的に減り DOP や粘度が上昇す るためである。

\section{$3 \cdot 1 \cdot 2$ 結晶化挙動}

結晶化挙動に関する最も重要なパラメーターは結晶化 温度であり, 使用する実験方法に依存する。結晶化挙動を 直接観察できる共焦点レーザー走査顕微鏡 (CLSM) およ びシングルホットサーモカップル (SHTT) の場合, 結晶化 温度は初期結晶核生成を観察できる温度に対応する。示差 走查熱量測定 (DSC) および示差熱分析 (DTA) の場合, 結 晶化温度は, 発熱ピーク前の熱流曲線の接線と急峻な発熱 ピーク曲線の接線の交点の温度に対応している。DSC およ びDTAから分析される体積熱は, 多大な変化が検出され るようになる前の顕著な結晶核生成と成長が必要である。 Fig.3 (a) が示す通り, $\mathrm{CaO}-\mathrm{Al}_{2} \mathrm{O}_{3}-\mathrm{SiO}_{2}-\mathrm{MgO}$ スラグ系にお ける結晶化温度は $\mathrm{Al}_{2} \mathrm{O}_{3} / \mathrm{SiO}_{2}$ 比の増加に伴って高くなっ た ${ }^{64)} 。 \mathrm{Al}_{2} \mathrm{O}_{3} / \mathrm{SiO}_{2}$ 比が増加するにつれて, 初相は Akermanite $\left(\mathrm{Ca}_{2} \mathrm{MgSi}_{2} \mathrm{O}_{7}\right)$ から Merwinite $\left(\mathrm{Ca}_{3} \mathrm{MgSi}_{2} \mathrm{O}_{8}\right)$ 八, そしてさら にGehlenite $\left(\mathrm{Ca}_{2} \mathrm{Al}_{2} \mathrm{SiO}_{7}\right)$ へと変化している。結晶化温度 における同様の上昇は $\mathrm{CaO}-\mathrm{SiO}_{2}-\mathrm{Al}_{2} \mathrm{O}_{3}-\mathrm{CaF}_{2}$ 系モールドフ ラックスにおいても観察された ${ }^{68)}$ 。しかし, Jung ら ${ }^{13)}$ は $17 \mathrm{wt} \%$ の $\mathrm{Na}_{2} \mathrm{O}$ と $\mathrm{Li}_{2} \mathrm{O}$ を含有する $\mathrm{CaO}-\mathrm{Al}_{2} \mathrm{O}_{3}-\mathrm{SiO}_{2}-\mathrm{Na}_{2} \mathrm{O}-$ 
$\mathrm{Li}_{2} \mathrm{O}$ スラグ系において $\mathrm{Al}_{2} \mathrm{O}_{3} / \mathrm{SiO}_{2}$ 比が増加するにつれて初 期の結晶化温度について反対の傾向を観察している。この 現象はケイ酸カルシウムナトリウム $\left(\mathrm{Na}_{2} \mathrm{Ca}_{3} \mathrm{Si}_{2} \mathrm{O}_{8}\right)$ から結 晶化温度が低いCaswellite $\left(\mathrm{Ca}_{3} \mathrm{Al}_{2} \mathrm{Si}_{3} \mathrm{O}_{12}\right)$ へと一次結晶相 が変化したことに起因していると考えられる。 $\mathrm{CaO}-\mathrm{SiO}_{2}-$ $\mathrm{Al}_{2} \mathrm{O}_{3}-\mathrm{B}_{2} \mathrm{O}_{3}-\mathrm{Na}_{2} \mathrm{O}$ フラックス系では, Wollastonite $\left(\mathrm{CaSiO}_{3}\right)$ と Combeite $\left(\mathrm{Na}_{2} \mathrm{Ca}_{2} \mathrm{Si}_{3} \mathrm{O}_{9}\right)$ の組み合わせが $\mathrm{CaO} / \mathrm{SiO}_{2}$ 比 0.8 という低い比率に打いて結晶化し, $\mathrm{CaO} / \mathrm{SiO}_{2}$ 比が 1.5 以上 では $\mathrm{Ca}_{3} \mathrm{Si}_{2} \mathrm{O}_{7}$ と $\mathrm{Ca}_{11} \mathrm{Si}_{4} \mathrm{~B}_{2} \mathrm{O}_{2}$ 二相へと移行する ${ }^{91)}$ 。CaO- $\mathrm{SiO}_{2}$ 系フラックス系に打ける更なる $\mathrm{B}_{2} \mathrm{O}_{3}$ 添加によって連続冷 却中の結晶化温度が低下し, 恒温冷却中の核生成のイン キュベーション時間が長くなることで結晶化が阻害され る ${ }^{96)}$ 。予測通り, モールドフラックスを構成している成分 によって異なる結晶化挙動が発生する。

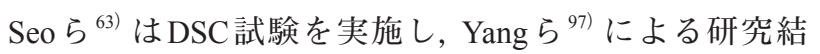
果と同様に, $\mathrm{CaO}-\mathrm{SiO}_{2}$ 系スラグにおける $1.8 \mathrm{wt} \%$ の $\mathrm{Li}_{2} \mathrm{O}$ 添 加により結晶化温度が低くなることを明らかにした。しか し，さらなる $\mathrm{Li}_{2} \mathrm{O}$ の添加は $\mathrm{LiAlO}_{2}$ の形成を促進させる可 能性があり ${ }^{98)}$, 液相スラグにおける初期核生成の駆動力を 増加させる。 $\mathrm{Li}_{2} \mathrm{O}$ 添加による粘度の低下により, イオン種 の拡散が促進され，初晶の成長速度が増大しうる ${ }^{99)}$ 。

Jiang ${ }^{100)}$ はSHTTを用いて $\mathrm{CaO}-\mathrm{Al}_{2} \mathrm{O}_{3}$ 系モールドフラッ クスの温度時間変態 (TTT) 曲線と連続冷却変態 (CCT) 曲 線を測定し, $\mathrm{CaO} / \mathrm{Al}_{2} \mathrm{O}_{3}$ 比 0.8 から 1.2 の範囲において $\mathrm{Al}_{2} \mathrm{O}_{3}$ 添加が結晶化を促進する可能性を見出した。加えて, $\mathrm{CaO} /$ $\mathrm{Al}_{2} \mathrm{O}_{3}$ 比の低下に伴って臨界冷却速度と結晶化温度は上昇 し, インキュベーション時間は短くなった。 $\mathrm{Al}_{2} \mathrm{O}_{3}$ 濃度の増 加において観察される粘度の上昇は連続鋳造におけるモー ルドフラックスの流動性の要件を満たせるものの ${ }^{94)}, \mathrm{CaO}-$ $\mathrm{Al}_{2} \mathrm{O}_{3}$ 系モールドフラックスの液相線温度や初期結晶化温 度は $\mathrm{Al}_{2} \mathrm{O}_{3}$ 濃度の増加につれて劇的に上昇する。高 $\mathrm{Al}$ 鋼の 鋳造において, 通常, フラックス中の $\mathrm{Al}_{2} \mathrm{O}_{3}$ 濃度は最適な 鋳造に必要な条件を超える ${ }^{93,94)}$ 。

高 $\mathrm{A} 1$ 鋼の鋳造における $\mathrm{CaO}-\mathrm{Al}_{2} \mathrm{O}_{3}$ 系モールドフラックス
での著しい結晶化やその後の潤滑の不足という問題を解決 するために, $\mathrm{B}_{2} \mathrm{O}_{3}, \mathrm{Li}_{2} \mathrm{O}, \mathrm{Na}_{2} \mathrm{O}$ および $\mathrm{BaO}$ などの添加剤が 単独または組み合わせて用いられてきた。

SHTTを用いた測定に打いて, $9 \mathrm{wt} \% \mathrm{CaF}_{2}$ を含む $\mathrm{CaO}-$ $\mathrm{Al}_{2} \mathrm{O}_{3}$ 系フラックスに拈ける一次相のインキュベーション 時間は $\mathrm{Li}_{2} \mathrm{O}$ 濃度が $1 \mathrm{wt} \%$ から $4.5 \mathrm{wt} \%$ に増加するにつれて 増加し, さらに $\mathrm{Li}_{2} \mathrm{O}$ 濃度が $6 \mathrm{wt} \%$ にまで増加すると $\mathrm{LiAlO}_{2}$ の晶出により減少した ${ }^{101)}$ 。Fluorite $\left(\mathrm{CaF}_{2}\right)$ の結晶化温度は $\mathrm{Li}_{2} \mathrm{O}$ 濃度が増えると低くなるため, 初相にはより大きな過 冷却が必要となり ${ }^{98)}$, インキュベーション時間も長くなっ た。 $\mathrm{Lu}{ }^{98)}$ は $\mathrm{CaO}-\mathrm{Al}_{2} \mathrm{O}_{3}$ 系モールドフラックスにおける $\mathrm{Li}_{2} \mathrm{O}$ と $\mathrm{Na}_{2} \mathrm{O}$ が結晶化挙動に影響する上で類似の役割を果 たしており, これらのフラックス材の添加が結晶化温度を 下げインキュベーション時間を増やすことで結晶化を阻害 する傾向があることを明らかにした。しかしながら, $\mathrm{Li}_{2} \mathrm{O}$ と $\mathrm{Na}_{2} \mathrm{O}$ 濃度がそれぞれ $7 \mathrm{wt} \%$ と $13 \mathrm{wt} \%$ を超えると結晶化 が $\mathrm{LiAlO}_{2}$ と Carnegieite $\left(\mathrm{Na}_{\mathrm{x}} \mathrm{Al}_{\mathrm{y}} \mathrm{Si}_{\mathrm{z}} \mathrm{O}_{4}\right)$ 結晶相の形成によっ て加速された。

その他の研究では, $\mathrm{BaO} の$ 融点 $(2196 \mathrm{~K})$ が $\mathrm{CaO}$ の融 点 $(2846 \mathrm{~K})$ よりも各段に低いことから, $\mathrm{BaO}$ がフラッ クスの結晶化速度を制御できる可能性が指摘されてい る $^{69,74,102,103)}$ 。 Lu and Wang ${ }^{69)}$ と Yan ${ }^{74)}$ は $\mathrm{CaO}$ を部分的に $\mathrm{BaO}$ に置換することで, Fig.3 (b) に示す通り, インキュベー ション時間を伸ばし $\mathrm{CaO}-\mathrm{Al}_{2} \mathrm{O}_{3}$ 系モールドフラックスの結 晶化を阻害できることを観察した。このアプローチはモー ルドフラックスに打ける潜在的なガラス化の割合を増加さ せることができ, 連続鋳造における潤滑にとって助けとな る ${ }^{94,104)}$ 。 $\mathrm{CaO}$ を $\mathrm{BaO}$ に置換すると結晶化を阻害できるもの の, $\mathrm{CaO}-\mathrm{Al}_{2} \mathrm{O}_{3}$ 系フラックスの連続冷却においてアルミン 酸バリウムカルシウム $\left(\mathrm{BaCa}_{2} \mathrm{Al}_{8} \mathrm{O}_{15}\right)$ 初相が晶出すること が知られている ${ }^{105)}$ 。しかし, Wang and Sohn ${ }^{55,90)}$ によると, $\mathrm{CaO}$ を等モル量の $\mathrm{BaO}$ で置換することにより $\mathrm{CaO}-\mathrm{Al}_{2} \mathrm{O}_{3}$ 系 モールドフラックスの液相線温度を下げ, 結晶化を阻害で きるものの, $\mathrm{CaO}$ の $\mathrm{BaO}$ による置換には制限も伴う。 $\mathrm{BaO}$
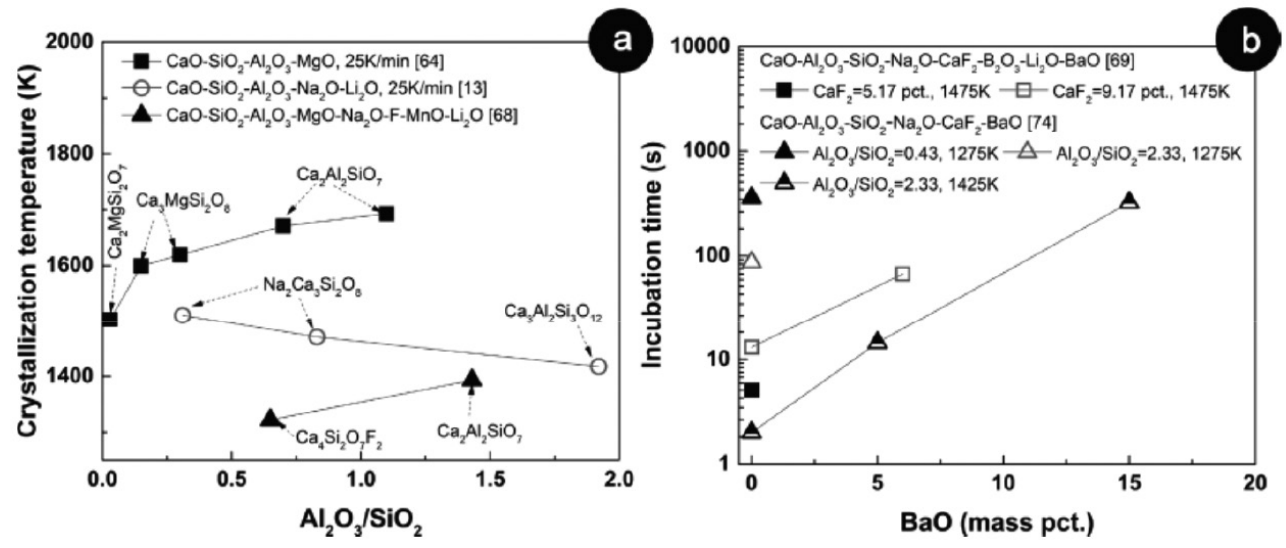

Fig. 3. (a) Crystallization temperature of mold fluxes with different $\mathrm{Al}_{2} \mathrm{O}_{3} / \mathrm{SiO}_{2}$ ratios and (b) incubation time of mold fluxes with different $\mathrm{BaO}$ contents. Adapted from published literature. ${ }^{13,64,68,69,74)}$ 
が徐々に $\mathrm{CaO}$ に取って代わるにつれ，モールドフラックス の粘度も大きく上昇する点も検討すべきであり，結晶化を 阻害するために用いる $\mathrm{BaO}$ の最適量は粘度の増加の影響 とのバランスを困る必要もある ${ }^{55,58,90)}$ 。

加えて, Fig.3 (b) では $\mathrm{CaF}_{2}$ 濃度が低下するとインキュ ベーション時間が短くなり，より高い核生成温度を伴う Gehleniteの形成を加速化することで結晶化が促進する ことを示している ${ }^{65,69)}$ 。さらに, Fig.3 (b) に示している 通り，フッ素を含むモールドフラックスに抏いて $\mathrm{Al}_{2} \mathrm{O}_{3}$ / $\mathrm{SiO}_{2}$ 比が高まるにつれてインキュベーション時間も急激 に減った ${ }^{74)}$ この現象はFig.4に示している通り, 初相が Cuspidine から Gehleniteへと変化したためであると考えら れる ${ }^{63,78,106)}$ 。

\section{$3 \cdot 1 \cdot 3$ 熱伝達挙動}

銅鋳型を通じた総括熱伝達は伝導熱と輻射熱の和であ り，モールドフラックスフィルムの特性によって左右され る ${ }^{107)}$ 。このフィルムは水冷銅鋳型と部分凝固シェルの間 にある液相，ガラス相，および結晶相によって構成されて いる。これらの相の割合は結晶化挙動を含むフラックスの 特性に依存している ${ }^{107)}$ 。総括熱伝達量 $\left(q_{T o t}\right)$ は次の式に よって表すことができる ${ }^{10,107)}$

$$
q_{\text {Tot. }}=q_{\text {Rad. }}+q_{\text {Cond. }}=q_{\text {Tot. }}^{\text {Glass }}+q_{\text {Tot. }}^{\text {Cryst. }}+q_{\text {Tot. }}^{\text {Liq. }}
$$

ここで， $q_{\text {Rad. }}$ と $q_{\text {Cond. }}$ はそれぞれ輻射機構と伝導機構による
スラグフィルムを通じた熱伝達量である。

モールドフラックスの結晶化により，銅鋳型とモールド フラックスの間に打ける界面に扎いて不均衡な空隙を形成 して熱抵抗が大きくなり, 熱伝達量が低下する。加えて, スラグフィルムに存在している微結晶による散乱も輻射を 阻害する ${ }^{10,107)}$ 。

凝固シェルと鋳型の間における総括熱伝達抵抗 $\left(R_{\text {Tot. }}\right)$ は 抵抗の直列として捉えることができ, 以下の式によって表 すことができる ${ }^{15,107)}$

$$
\begin{aligned}
& R_{\text {Tot. }}=R^{\text {Int. }}+R^{\text {Liq. }}+R^{\text {Glass. }}+R^{\text {Cryst. }}= \\
& R^{\text {Int. }}+(d / q)^{\text {Liq. }}+(d / q)^{\text {Glass. }}+(d / q)^{\text {Cryst. }}
\end{aligned}
$$

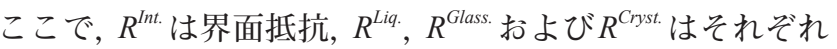
液相，ガラス相，および結晶相における抵抗， $d$ は各相の厚 さである。固相スラグ厚みや結晶化度の増加と共に $R^{I n t}$ も 増加することが明らかになっているため, 熱伝達に影響す る主な要因は固相スラグフィルムと結晶の厚みである ${ }^{15)}$ 。 そのため，モールドフラックスの結晶化挙動の理解は鋳型 内における総括熱伝達の制御において必要不可欠である。

$\mathrm{CaO}-\mathrm{SiO}_{2}$ 系モールドフラックスについては, 溶鋼と鋳 型の間における熱伝達を効果的に制御するため晶出した Cuspidineの初相が一般的に用いられる ${ }^{108)}$ 。しかし, $\mathrm{Al}_{2} \mathrm{O}_{3}$ l $\mathrm{SiO}_{2}$ 比や $\mathrm{CaO} / \mathrm{SiO}_{2}$ 比の変化により, Cuspidineの形成や成長 速度, 形態，および分布は多大な影響を受け，鋳型内におい

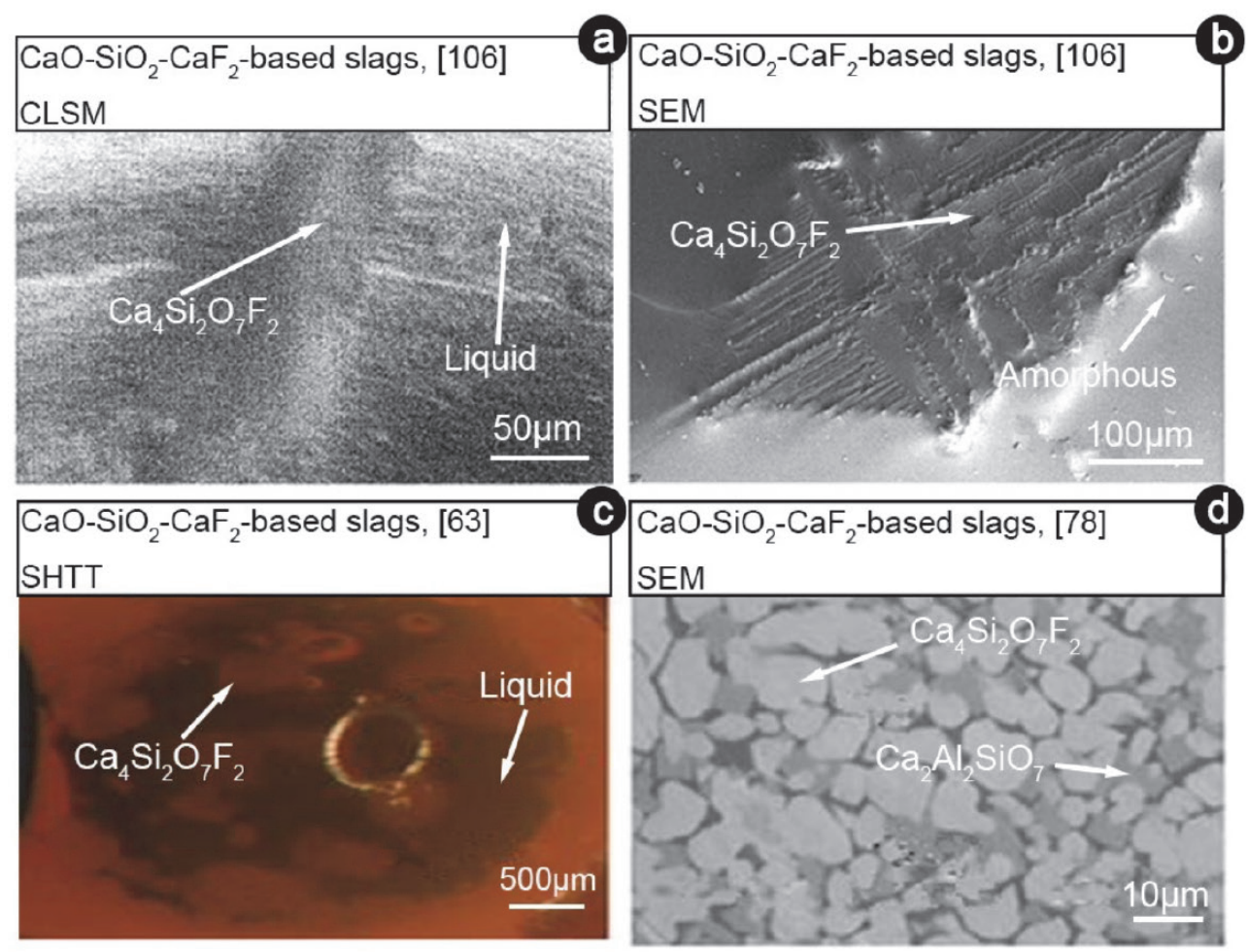

Fig. 4. (a) Morphology of cuspidine $\left(\mathrm{Ca}_{4} \mathrm{Si}_{2} \mathrm{O}_{7} \mathrm{~F}_{2}\right)$ obtained by CLSM, (b) morphology of cuspidine obtained by SEM, (c) morphology of cuspidine obtained by SHTT, and (d) morphologies of cuspidine and gehlenite $\left(\mathrm{Ca}_{2} \mathrm{Al}_{2} \mathrm{SiO}_{7}\right)$ obtained by SEM. Adapted from published literature. ${ }^{63,78,106)}$ (Online version in color.) 
て最適でない不均質な熱伝達という結果をもたらす。その ため, 高 $\mathrm{A} 1$ 鋼の鋳造におけるモールドフラックスの熱伝導 の性能を最適化するためいくつかの研究が行われている。

$6 \mathrm{wt} \% \mathrm{CaF}_{2}$ を含む $\mathrm{CaO}-\mathrm{Al}_{2} \mathrm{O}_{3}$ 系フラックスにおいて $\mathrm{Al}_{2} \mathrm{O}_{3}$ 濃度が $7 \mathrm{wt} \%$ から $30 \mathrm{wt} \%$ へと増加するにつれて, 初相は Cuspidineから Carnegieiteへ, そしてさらにFluoriteへと変 化し, 結晶化温度は低下寸る。 $\mathrm{Al}_{2} \mathrm{O}_{3}$ 濃度がさらに $40 \mathrm{wt} \%$ まで増加するにつれて, 初相は高い結晶化温度を有する Gehleniteへと変化する。初相の変化と結晶化温度の低下 に伴い, $\mathrm{Al}_{2} \mathrm{O}_{3}$ 濃度が $7 \mathrm{wt} \%$ から $30 \mathrm{wt} \%$ へと増加するに つれて熱流束が徐々に低下し, その後 $\mathrm{Al}_{2} \mathrm{O}_{3}$ 濃度がさらに $40 \mathrm{wt} \%$ まで増加すると熱流束は増加し, $\mathrm{Al}_{2} \mathrm{O}_{3}$ 濃度の増加 による結晶層厚みや結晶化率が示している傾向とは半比例 している ${ }^{83)}$ 。

$\mathrm{CaO}-\mathrm{Al}_{2} \mathrm{O}_{3}$ 系モールドフラックスに打いて $2-5 \mathrm{wt} \%$ の $\mathrm{Li}_{2} \mathrm{O}$ を添加すると, インキュベーション時間は短くなり, 結晶化温度が上昇して, 熱流束が低下する ${ }^{76)}$ 。同じスラグ 系について, Wang ら ${ }^{77)}$ は $\mathrm{Na}_{2} \mathrm{O}$ 濃度が増加するにつれて非 反応性モールドフラックスのインキュベーション時間も増 加することを観察した。抑制された結晶化挙動によりスラ グリムの成長の阻害につながり，高 $\mathrm{A} 1$ 鋼の連続鋳造におけ る熱流束も増加する。

\section{$3 \cdot 2$ 高 $\mathrm{Mn}$ 鋼におけるフラックスの開発}

\section{$3 \cdot 2 \cdot 1$ 粘性挙動}

低 $\mathrm{Al}$ 高 $\mathrm{Mn}$ 鋼については，スラグと金属の間における

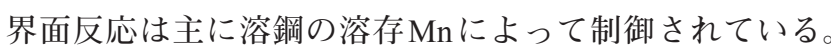
Yang and $\mathrm{Zhu}^{25)}$ は 高 $\mathrm{Mn}$ 鋼 $(\mathrm{Mn}=5-18 \mathrm{wt} \% ; \mathrm{Al}=0.004$ $0.01 \mathrm{wt} \%)$ と $\mathrm{CaO}-\mathrm{SiO}_{2}$ 系フラックス系の間における反応を 調査し，モールドフラックスの $\mathrm{MnO}$ 濃度が 30 分で $12 \mathrm{wt} \%$ に達し，さらにモールドフラックスの $\mathrm{CaO} / \mathrm{SiO}_{2}$ 比が高いほ ご $\mathrm{MnO}$ 濃度の増加を抑えることができることを明らかに した。また, 融体の $\mathrm{MnO}$ 濃度が高くなり $\mathrm{SiO}_{2}$ 濃度が低くな るにつれてスラグ粘度が連続的に低下寸ることも確認し た。この挙動は融体内において $\mathrm{O}^{2-}$ が増加して $\left[\mathrm{SiO}_{4}\right]$-四 面体構造単位から形成される複雑なオリゴマー構造が減少 し，スラグの DOPを減らし粘性流に必要なせん断応力を低 下させるためである。 $\mathrm{MnO}$ 濃度の増加と $\mathrm{SiO}_{2}$ 濃度の減少 に伴い，メニスカスに打けるスラグリムの低減に対して有 益であることが知られている break temperature（注：冷却 過程での粘度測定において急激な粘度増加が始まる温度) の低下も観察され，潤滑が向上し熱抵抗が減少した。

$\mathrm{Al}$ 含有高 $\mathrm{Mn}$ 鋼の卓越した機械特性により，高 $\mathrm{Mn}$ 鋼や 高 $\mathrm{A} 1$ 鋼用モールドフラックス系の熱物性に関して数々の 研究が行われてきた。Kim ら ${ }^{18,26)}$ は高 Mn鋼や高 $\mathrm{A} 1$ 鋼 $(\mathrm{Mn}$ =13-20.8 wt \% $\mathrm{Al}=0.4-5.2 \mathrm{wt} \%)$ と $\mathrm{CaO}-\mathrm{SiO}_{2}$ 系モールド フラックスの間における反応を調べ, $\mathrm{Al}_{2} \mathrm{O}_{3}$ が増加したこ とに加え, 反応の始めに $\mathrm{MnO}$ が急激に増加しその後急速 に減少したことを確認した。 $\mathrm{Mn}$ は当初 $\mathrm{SiO}_{2}$ によって酸化
され，その後溶鋼の高濃度の $\mathrm{Al}$ にって還元された。加え て,モールドフラックスの $\mathrm{CaO} / \mathrm{SiO}_{2}$ 比が低く, 鋼の $\mathrm{Al}$ 濃度 が低く，および温度が高いほど溶融したフラックスに打け る $\mathrm{MnO}$ 濃度が高くなり, $\mathrm{CaO} / \mathrm{SiO}_{2}$ 比 0.3 において $\mathrm{MnO}$ 濃 度は約 $7 \mathrm{wt} \%$ となった ${ }^{18)}$ 。 $\mathrm{Al}_{2} \mathrm{O}_{3}$ と $\mathrm{MnO}$ は両方ともフラッ クスに蓄積されるものの, $\mathrm{Al}$ とフラックスとの反応は $\mathrm{Mn}$ との反応と比べ，より熱力学的に起こりやすいため, 定常 状態において $\mathrm{Al}_{2} \mathrm{O}_{3}$ 濃度が高い状態で $\mathrm{MnO}$ とのバランスを 図る ${ }^{17,18,109,10)}$ 。

高 $\mathrm{Mn}$ 高 $\mathrm{A} 1$ 鋼の鋳造におけるモールドフラックスの粘度 を最適化するため, いくつかの研究において $\mathrm{CaO} / \mathrm{SiO}_{2}$ 比, $\mathrm{Al}_{2} \mathrm{O}_{3} / \mathrm{SiO}_{2}$ 比，またはフラックス材の添加による影響を観 察している ${ }^{14,42,52,53,57,111)}$ 。前節で触れたモールドフラックス の粘度の最適化に関する研究の多くは高Al TRIP鋼や高 $\mathrm{Mn}$ 高Al TWIP鋼に基づいていたため，高 $\mathrm{Mn}$ 高A1鋼向け モールドフラックスに打ける粘性挙動のほとんどは高 $\mathrm{Al}$ 鋼向けモールドフラックスの粘性挙動としてみなすことが できる。加えて, He ${ }^{112)}$ 多成分かつ相応の組成を用いて $\mathrm{CaO}$ や $\mathrm{SiO}_{2}$ の濃度を減らし他のフラックス材を増加させ, それによりモールドフラックスの性能の安定性を担保で きることを明らかにした。 $\mathrm{MnO}$ の添加により $\mathrm{Al}$ と $\mathrm{MnO}$ の 間で発生する反応を加速化させて, $\mathrm{Al}$ と $\mathrm{SiO}_{2}$ の間に打ける 反応を部分的に抑制できることが見出された。 $\mathrm{MnO}$ は $\mathrm{SiO}_{2}$ と比ベスラグ特性への影響が少ないため, $\mathrm{MnO}$ を活用する ことでモールドフラックスの熱物性に対して $\mathrm{SiO}_{2}$ 濃度の 大きな変化によるデメリットを削減できる可能性がある。

高 $\mathrm{Mn}$ 高 $\mathrm{A} 1$ 鋼の連続鋳造における溶融スラグの組成 の変化を推定する計算モデルもいくつか開発されてい

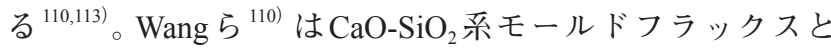
20Mn23AlV $(\mathrm{Mn}=21-25 \mathrm{wt} \%)$ 鋼の間に打ける反応を調 ベ, 鋳造中のモールドフラックスに打ける $\mathrm{Al}_{2} \mathrm{O}_{3}$ の蓄積を 予測するモデル式を構築した。また, Kim and Kang ${ }^{113)}$ は高 $\mathrm{Mn}$ 高 $\mathrm{A} 1$ 鋼と $\mathrm{CaO}-\mathrm{SiO}_{2}$ 系フラックスの間に打ける複合反 応を記述するため多成分反応モデルを開発している。モデ ルの影響要因に基づき, 連続鋳造中の鋼やフラックスにお ける組成変化を再現でき，フラックスの粘度や結晶化挙動 を予測しフラックス性能の低下が発生した場合にその補償 に必要な成分を特定する上でモデルを活用できる可能性を 示した。

\section{$3 \cdot 2 \cdot 2$ 結晶化挙動}

低 $\mathrm{Al}$ 高 $\mathrm{Mn}$ 鋼については, $\mathrm{CaO} / \mathrm{SiO}_{2}$ 比と $\mathrm{MnO}$ 濃度が増 加するにつれて結晶化温度が最初に上昇しその後低下し た ${ }^{25)}$ 。MnO濃度が増加するにつれて, Tephroite $\left(\mathrm{Mn}_{2} \mathrm{SiO}_{4}\right)$ 結晶がCuspidine内の $\left[\mathrm{SiO}_{4}\right]$ - 四面体構造単位を消費する ことで形成され，連続冷却中における Cuspidine 結晶の割 合の低下につながった。

高 $\mathrm{Mn}$ 高 $\mathrm{A}$ 鋼の鋳造については既に述べている通り， モールドフラックスに打ける支配的な組成変化は $\mathrm{Al}_{2} \mathrm{O}_{3}$ の 
蓄積と $\mathrm{SiO}_{2}$ の消費であり，高 $\mathrm{A} 1$ 鋼の鋳造と同様のモール ドフラックスの結晶化挙動に影響するような $\mathrm{Al}_{2} \mathrm{O}_{3} / \mathrm{SiO}_{2}$ 比 の急激な上昇が検出される。そのため, 結晶化挙動の最適 化に向けた $\mathrm{Al}_{2} \mathrm{O}_{3} / \mathrm{SiO}_{2}$ 比やその他のフラックス材の添加の 影響については高 $\mathrm{A} 1$ 鋼に関する前述の議論において触れ ている。

一部の具体的な高 $\mathrm{Mn}$ 高 $\mathrm{Al}$ 鋼の鋳造中のモールドフ ラックスに打ける結晶化挙動についてこれより述べる。 $20 \mathrm{Mn} 23 \mathrm{AlV}(\mathrm{Mn}=21-25 \mathrm{wt} \%)$ 非磁性鋼の鋳造のため低 融点で低 $\mathrm{CaO} / \mathrm{SiO}_{2}$ 比の従来の $\mathrm{CaO}-\mathrm{SiO}_{2}$ 系モールドフラッ クスを用いて, $\mathrm{Yu} ら^{114)}$ は $\mathrm{Al}_{2} \mathrm{O}_{3} / \mathrm{SiO}_{2}$ 比の増加によりスラ グ融体における Fluorite結晶の核生成が促進されることを 観察した。高 $\mathrm{Mn}$ 高 $\mathrm{Al}$ 鋼の鋳造中における金属とスラグの 相互作用を抑え，熱流束を制御できる可能性がある非反 応性 $\mathrm{CaO}-\mathrm{Al}_{2} \mathrm{O}_{3}$ 系モールドフラックスの最適化について は多大な努力が費やされてきた。非磁性 20Mn23AlV（Mn $=21-25 \mathrm{wt} \%)$ 鋼については, $\mathrm{Al}$ と $\mathrm{SiO}_{2}$ の間における反 応により高い融解温度と高い粘度という結果につながり, フラックスにおける Gehlenite結晶の核生成と緩やかな成 長という大きな傾向をもたらす战。高 $\mathrm{Al}_{2} \mathrm{O}_{3} / \mathrm{SiO}_{2}$ 比は結 晶化温度を上昇させインキュベーション時間を短縮し， 全体的な熱伝達を下げている ${ }^{74)}$ 。状態図からは, $\mathrm{Al}_{2} \mathrm{O}_{3}$ 濃 度が高く $\mathrm{CaO} / \mathrm{SiO}_{2}$ 比が増加すると, 晶出相が低い結晶化 温度を伴うWollastonite から比較的高い結晶化温度を伴う Gehleniteへシフトするように促進させることができると 推論される。この推論は, $20 \mathrm{wt} \%$ 以上の $\mathrm{Al}_{2} \mathrm{O}_{3}$ 濃度により Gehleniteの形成を促進させCuspidineの形成を阻害したと いう Hiromoto ら ${ }^{116)}$ による報告内容と一致しているように 見える。Cuspidineの形成によって消費されなかった余剩の $\mathrm{F}$ 一は $\mathrm{Ca}^{2+}$ と合体し Fluoriteが晶出する。

Yan ${ }^{66)}$ は0.6から 3.2 までの広範な $\mathrm{CaO} / \mathrm{Al}_{2} \mathrm{O}_{3}$ 比がもた らす20Mn23AlV $(\mathrm{Mn}=21-25 \mathrm{wt} \%)$ 鋼の鋳造用モール ドフラックスにおける結晶化挙動への影響を調べ, $\mathrm{CaO} /$ $\mathrm{Al}_{2} \mathrm{O}_{3}$ 比を増加させることにより, 結晶化温度が低下した
のちに上昇することで結晶化が最初は阻害されその後促 進されていることを明らかにした。さらに，Yanらは CaO/ $\mathrm{Al}_{2} \mathrm{O}_{3}$ 比を増加させることでインキュべーション時間がま ず増加しその後減少することも確認した。加えて, 低い粘 度を伴う高い $\mathrm{CaO} / \mathrm{Al}_{2} \mathrm{O}_{3}$ 比により物質移動抵抗を低下させ 結晶の成長速度を増加できることも明らかにした。

非反応性 $\mathrm{CaO}-\mathrm{Al}_{2} \mathrm{O}_{3}$ 系モールドフラックスの結晶化挙動 に扎いて $\mathrm{CaF}_{2}$ を $\mathrm{B}_{2} \mathrm{O}_{3}$ で置換することによる影響として， 結晶化温度を低下させ結晶化にかかるインキュベーショ ン時間を延長させることで $\mathrm{CaF}_{2}$ が $\mathrm{CaO}-\mathrm{Al}_{2} \mathrm{O}_{3}$ 系モールド フラックスの結晶化を阻害して打り ${ }^{65)}, \mathrm{CaO}-\mathrm{SiO}_{2}$ 系モー ルドフラックスが示していた挙動とは反対であった ${ }^{32)} 。 ま$ た，最大 $20 \mathrm{wt} \%$ までの $\mathrm{CaF}_{2}$ 濃度において， $5 \mathrm{wt} \%$ の $\mathrm{SiO}_{2}$ を 含む $\mathrm{CaO}-\mathrm{Al}_{2} \mathrm{O}_{3}$ 系モールドフラックスに扎いて Cuspidine は形成されなかった。 $\mathrm{CaF}_{2}$ 濃度が減少するにつれて, 一次 結晶相もアルミン酸カルシウムフッ化物 $\left(\mathrm{Ca}_{2} \mathrm{Al}_{3} \mathrm{O}_{6} \mathrm{~F}\right)$ から Gehleniteへと変化した。フッ化物を含まない $\mathrm{CaO}-\mathrm{Al}_{2} \mathrm{O}_{3}$ 系 モールドフラックスへの $10 \mathrm{wt} \%$ から $20 \mathrm{wt} \%$ までの $\mathrm{B}_{2} \mathrm{O}_{3}$ 添 加により Gehleniteの結晶化を阻害し，より低度における Takedaite $\left(\mathrm{Ca}_{3} \mathrm{~B}_{2} \mathrm{O}_{6}\right)$ の形成を促進する ${ }^{65)}$ 。

$3 \cdot 2 \cdot 3$ 熱伝達挙動

低 $\mathrm{Al}$ 高 $\mathrm{Mn}$ 鋼については, $\mathrm{CaO}-\mathrm{SiO}_{2}$ 系モールドフラック スの熱伝導率は $\mathrm{MnO}$ 含有量の増加とともに減少した ${ }^{117)}$ 。 $\mathrm{MnO}$ の添加により, $\mathrm{O}^{2-}$ が複雑なケイ酸塩ネットワークを 切断し, Cuspidineの分解や熱伝導率が低く低融点である Tephroite $\left(\mathrm{Mn}_{2} \mathrm{SiO}_{4}\right)$ 相の生成が生じて, それにより低い伝 導性の熱伝達に至った ${ }^{118)}$

高 $\mathrm{Al}$ 高 $\mathrm{Mn}$ 鋼については, $\mathrm{Al}_{2} \mathrm{O}_{3} / \mathrm{SiO}_{2}$ 比の増加により Cuspidineから高い結晶化温度を有する Gehleniteへの一次 相の変化を促進させ，それにより Fig.5 (a)に示す通り，ス ラグフィルムの熱伝導率を下げることで熱伝達を阻害し た ${ }^{74,75)}$ 。そのため, 高 $\mathrm{Al}_{2} \mathrm{O}_{3} / \mathrm{SiO}_{2}$ 比の場合に熱伝達が阻ま れて，スラブの品質や鋳造工程の安定性に悪影響を及ぼ す $^{74)}$ 。
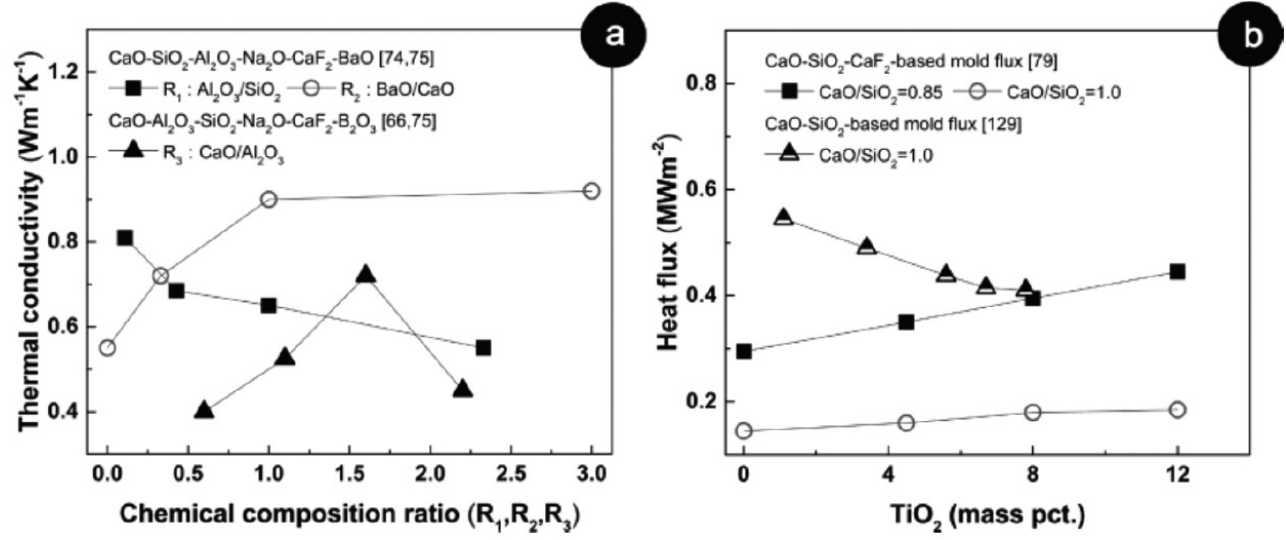

Fig. 5. (a) Thermal conductivity of mold fluxes with different chemical composition ratios $\left(\mathrm{R}_{1}: \mathrm{Al}_{2} \mathrm{O}_{3} / \mathrm{SiO}_{2} ; \mathrm{R}_{2}: \mathrm{BaO} / \mathrm{CaO}\right.$; and $\mathrm{R}_{3}: \mathrm{CaO} /$ $\mathrm{Al}_{2} \mathrm{O}_{3}$ ) and (b) heat flux of mold fluxes with different $\mathrm{TiO}_{2}$ contents. Adapted from published literature. ${ }^{66,74,75,79,129)}$ 
一部の研究では, $\mathrm{CaO}$ を $\mathrm{BaO} に よ り$ 置換することで $\mathrm{CaO}-\mathrm{Al}_{2} \mathrm{O}_{3}$ 系フラックスの結晶化挙動に関する懸念に対 応し, $\mathrm{Al}_{2} \mathrm{O}_{3} / \mathrm{SiO}_{2}$ 比が高まった際に結晶化温度を下げイ ンキュベーション時間を延長できることが示されてい る ${ }^{69,74)}$ 。そのため, $\mathrm{CaO}$ を $\mathrm{BaO}$ により部分的に置換するこ とで, Fig.5 (a) に示しているように, 高 $\mathrm{Al}$ 高 $\mathrm{Mn}$ 鋼の鋳造 中に打ける $\mathrm{Al}_{2} \mathrm{O}_{3} / \mathrm{SiO}_{2}$ 比の増加によってもたらされる熱伝 導率の低下を補償できる。

0.6 から 3.2 までの広範な $\mathrm{CaO} / \mathrm{Al}_{2} \mathrm{O}_{3}$ 比が結晶化挙動に及 ぼす影響についてさらに調査したYan ${ }^{66,75)}$ の研究では, Fig.5 (a) に示しているように, $\mathrm{CaO} / \mathrm{Al}_{2} \mathrm{O}_{3}$ 比の増加により 熱伝導率がまず上昇しその後低下した。この結果は, 初期 結晶化温度やインキュベーション時間に打ける変化によっ て示されているように, まず阻害されその後促進された結 晶化の挙動とよく整合している。

$\mathrm{B}_{2} \mathrm{O}_{3}$ は $\mathrm{CaO}-\mathrm{Al}_{2} \mathrm{O}_{3}$ 系モールドフラックスにおける熱流束 に対して $\mathrm{CaF}_{2}$ と同様の影響を示しているものの, 熱伝導率

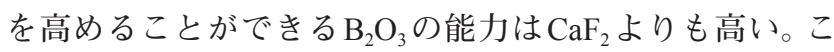
れは，フッ素を含有している $\mathrm{CaO}-\mathrm{Al}_{2} \mathrm{O}_{3}$ 系モールドフラッ クスに打いて生成する $\mathrm{Ca}_{2} \mathrm{Al}_{3} \mathrm{O}_{6} \mathrm{~F}$ の代わりに $\mathrm{Ca}_{3} \mathrm{~B}_{2} \mathrm{O}_{6}$ が形 成されたことに起因していると考えられる ${ }^{32,65)}$ 。

フラックスにもたらされる組成変化以外について見る と, Cho ${ }^{119)}$ が溶融フラックス供給を用いることにより高 $\mathrm{Mn}$ 高 $\mathrm{Al}(\mathrm{Fe}-18 \mathrm{Mn}-0.6 \mathrm{C}-1.5 \mathrm{Al})$ 鋼の鋳造性における顕著な 改善を観察している。厚い溶融プールを担保することで, フラックスと溶存元素の間における反応生成物が希䣋さ れ, $10 \mathrm{wt} \%$ 以下の $\mathrm{Al}_{2} \mathrm{O}_{3}$ 濃度増加を伴う比較的一定の $\mathrm{CaO} /$ $\mathrm{SiO}_{2}$ 比0.6が維持され, モールドフラックスの熱物性の安 定性が担保された。この融液供給によるアプローチの限界 として, 溶融スラグの経済性, 非反応性の追加的補助装置 が追加で必要である点, 気体性化学種の高い揮発性, およ び鉛直方向の放射熱の断熱を担保するためモールドカバー が必要となる点などが挙げられる。

\section{$3 \cdot 3$ 高 $\mathrm{Ti}$ 鋼におけるフラックスの開発}

\section{$3 \cdot 3 \cdot 1$ 粘性挙動}

Mills ${ }^{11)}$ によると, 高 Ti ステンレス鋼の連続鋳造工程にお いて直面する問題は, スラグと金属の反応に起因する $\mathrm{TiO}_{2}$ 濃度の増加や一般的な炭素鋼よりも低いオーステナイト系 ステンレス鋼の液相線温度に関係している。Mukongo ら ${ }^{19)}$ は $6 \mathrm{wt} \%$ Ti安定化オーステナイト系ステンレス鋼の鋳造に おけるモールドフラックスを採取し， 3-4 wt $\%$ の $\mathrm{TiO}_{2}$ 濃度 を観察した。この溶存 $\mathrm{Ti}$ 濃度は一般的ではないが, 複数の 鋼材生産者が $1 \mathrm{wt} \%$ を超える Tiを含む鋼材を生産してお り, 同様に $\mathrm{TiO}_{2}$ を形成する顕著な反応が起きているはずで ある。

$1563 \mathrm{~K}$ から $1623 \mathrm{~K}$ の範囲での高 $\mathrm{Ti}$ 安定化ステンレス鋼 の鋳造のモールドフラックスにおける $10 \mathrm{wt} \% \mathrm{TiO}_{2}$ にもの ぼる $\mathrm{SiO}_{2}$ の置換により, $\mathrm{TiO}_{2}$ 濃度の増加と共に粘度の低
下が見られた ${ }^{120)}$ 。れより低い温度では, $10 \mathrm{wt} \% \mathrm{TiO}_{2}$ の モールドフラックスの粘度は $\mathrm{TiO}_{2}$ を含有していないスラ グよりも高く, 固相の晶出に起因しているものと考えられ た。Wang ${ }^{28)}$ と Sun ら ${ }^{121)}$ は $\mathrm{CaO}-\mathrm{SiO}_{2}$ 系モールドフラック スにおける粘度を調べ, $\mathrm{TiO}_{2}$ 濃度が高いほど粘度が低くな ることを明らかにした。これらの研究結果はZheng ら ${ }^{122}$ による $\mathrm{CaO}-\mathrm{SiO}_{2}-\mathrm{TiO}_{2}$ スラグ系に関する研究結果や Park $ら^{123)}$ と Feng ら ${ }^{124)}$ による $\mathrm{CaO}-\mathrm{SiO}_{2}-\mathrm{Al}_{2} \mathrm{O}_{3}-\mathrm{MgO}-\mathrm{TiO}_{2}$ スラ グ系の研究結果と同等である。 $\mathrm{TiO}_{2}$ の添加については, 主 成分である $\mathrm{SiO}_{2}$ が減少することで $\left[\mathrm{SiO}_{4}\right]$ - 四面体構造単位 が切断されることと, Si-Oよりも Ti-O の結合エネルギーが 弱いことの $2 つ の$ 要因が一般的な要因であるように思われ る $^{28,120,122,123)}$ 。

高 $\mathrm{Ti}$ 鋼の鋳造における非反応性 $\mathrm{CaO}-\mathrm{Al}_{2} \mathrm{O}_{3}$ 系モールドフ ラックスに関する既存の文献では, 本分野に特化した研究 が少なく, 今後これまでより深く注目していくことが必要 になると考えられる。

\section{$3 \cdot 3 \cdot 2$ 結晶化挙動}

$\mathrm{CaO}-\mathrm{SiO}_{2}$ 系モールドフラックスによる高 $\mathrm{Ti}$ 鋼の鋳造に ついては, $\mathrm{F} を \mathrm{TiO}_{2}$ で置換することにより, Cuspidine相 の代わりにPerovskite一次結晶を生成し, 熱伝達を制御し ている ${ }^{27,125,126)}$ 。 $\mathrm{TiO}_{2}$ がスラグフィルムの赤外透過を減ら し輻射による熱伝達を阻害すると推測されている。加え て, Nakada and Nagata ${ }^{127)} も \mathrm{CaO}-\mathrm{SiO}_{2}-\mathrm{TiO}_{2}$ スラグにおける Titanite $\left(\mathrm{CaSiTiO}_{5}\right)$ の核生成に要するインキュベーション 時間が商用モールドフラックスに扎けるCuspidine相のそ れと同等であることを観察し，商用モールドフラックスに おけるCuspidineの様に $\mathrm{CaSiTiO}_{5}$ もスラグフィルムにおい て急速に結晶化できることが示唆された。

結晶化温度を比較し結晶成長の有効活性化エネルギー を評価することで, $\mathrm{SiO}_{2}$ の $\mathrm{TiO}_{2}$ による置換が $\mathrm{CaO}-\mathrm{SiO}_{2}-$ $\mathrm{CaF}_{2}$ 系モールドフラックスにおける主要なCuspidineの核 生成を抑制し Perovskiteの核生成に優位に働くことができ る ${ }^{120,128)}$ 。Cuspidine $\mathrm{TiO}_{2}$ を含まないスラグにおける優勢 な結晶相であるが, Perovskite相とCuspidine相の複合生成 が $5 \mathrm{wt} \%$ や $10 \mathrm{wt} \% \mathrm{TiO}_{2}$ において検出され, Perovskiteの割 合の方が大きい。Sun ら ${ }^{121)} も \mathrm{TiO}_{2}$ の添加により Cuspidine やWollastoniteの核生成を抑制し PerovskiteやMeliliteの 核生成を促進できることを観察した。0.85から 1.0 までの $\mathrm{CaO} / \mathrm{SiO}_{2}$ 比を有するモールドフラックスについては, $\mathrm{TiO}_{2}$ 濃度の増加につれて優勢な一次結晶相がCuspidineから Perovskiteへと変化し, $\mathrm{CaO} / \mathrm{SiO}_{2}$ 比が低いスラグにおいて はCuspidineの核生成量と成長速度が抑制された ${ }^{79)}$ 。フッ 素を含まない $\mathrm{CaO}-\mathrm{SiO}_{2}$ 系モールドフラックスでは, $\mathrm{TiO}_{2}$ 濃度が $5 \mathrm{wt} \%$ から $10 \mathrm{wt} \%$ へと増加するにつれて結晶化が 促進されインキュベーション時間も短縮化しており, これ は低いスラグ粘度や結晶化を加速化させることにつながる 物質移動の増加によるものであると考えられた ${ }^{28)}$ 。 


\section{$3 \cdot 3 \cdot 3$ 熱伝達挙動}

409 フェライト系ステンレス鋼 $(0 \mathrm{Cr} 11 \mathrm{Ti}, \mathrm{Ti}=6 \times$ $[\mathrm{wt} \% \mathrm{C}] \sim 0.75 \mathrm{wt} \%)$ や321オーステナイト系ステンレス 鋼 $(1 \mathrm{Cr} 18 \mathrm{Ni} 9 \mathrm{Ti}, \mathrm{Ti}=5 \times([\mathrm{wt} \% \mathrm{C}]-0.02 \mathrm{wt} \%) \sim 0.80 \mathrm{wt} \%)$ など，一部の特殊高 $\mathrm{Ti}$ 鋼のための $\mathrm{CaO}-\mathrm{SiO}_{2}$ 系モールドフ ラックスについては, $\mathrm{TiO}_{2}$ 濃度の増加と共にスラグフィル ムの熱流束や熱伝達係数の増加が見られ, Fig.5（b）に示し ている通り，このような効果は低 $\mathrm{CaO} / \mathrm{SiO}_{2}$ 比 ${ }^{79)}$ のモール ドフラックスにおいて，より顕著に見られた。この現象は， $\mathrm{TiO}_{2}$ 濃度が高く $\mathrm{CaO} / \mathrm{SiO}_{2}$ 比が低いほど Cuspidineの成長速 度が抑制され，結晶化温度が低下寸るためであると考えら れる。しかし，フッ素を含まない $\mathrm{TiO}_{2}$ 含有モールドフラッ クスに打ける Perovskiteの結晶化の促進により, Fig.5 (b) に示す通り $\mathrm{TiO}_{2}$ 濃度の増加と共に熱流束が小さくなるこ とが観察され ${ }^{129)}$ ，これによっても Perovskiteが Cuspidineの 代替となる可能性を有することを示唆している。Perovskite の形態はFig. $6^{130)}$ に示されており, Fig.4に示されている Cuspidineの形態と類似している。

$\mathrm{Al}$ と Ti 含むIncoloy-800 鋼の実際の連続鋳造において, スラブの表面割れの問題はモールドフラックスの熱伝達 挙動とIncoloy-800の凝固特性に深く関与していることが 示された。使用済みモールドフラックスの組成に基づき， モールドフラックスに打ける $\mathrm{CaO} / \mathrm{SiO}_{2}$ 比, $\mathrm{MnO}$ 濃度, およ び $\mathrm{CaF}_{2}$ 濃度の増加により熱伝達が妨げられ，一方， $\mathrm{BaO}$ $\mathrm{Al}_{2} \mathrm{O}_{3}$ 濃度の増加は熱伝達を増加させる傾向にあった ${ }^{82}$ 。 Yan ${ }^{82)}$ も熱伝達を促進し，核生成温度が高い Gehleniteや Perovskiteの晶出を抑制するため $\mathrm{CaO} / \mathrm{SiO}_{2}$ 比を下げること を検討した。低い $\mathrm{CaO} / \mathrm{SiO}_{2}$ 比，高い $\mathrm{CaF}_{2}, \mathrm{BaO}$ および $\mathrm{Al}_{2} \mathrm{O}_{3}$ 濃度, 低い $\mathrm{MnO}$ 濃度などといった対応する組成を調整す ることにより，新たに設計したモールドフラックスの溶融 温度が下がり，結晶の割合が低く良好な潤滑特性が提供さ れ，それにより部分凝固シェルを厚くし強化するために熱 伝達が促進される。

\section{4. 展望}

高合金鋼を鋳造するための $\mathrm{CaO}-\mathrm{SiO}_{2}$ 系および $\mathrm{CaO}-\mathrm{Al}_{2} \mathrm{O}_{3}$ 系モールドフラックスの熱物理的特性を厳密に評価した。 基本的な熱力学的反応を見越してモールドフラックスの組 成を変化させ，様々なフラックス材で多成分フラックス系 に補正することで, 連続鋳造用モールドフラックスに必要 な熱物性を実現できる。反応性の $\mathrm{CaO}-\mathrm{SiO}_{2}$ 系モールドフ ラックスについては，スラグ/鋼反応の阻害または補償を 狙い異なる種類や濃度のフラックス材を添加することで熱 物性を安定化させる必要があり，それによりスラグ/鋼反 応が $\mathrm{Al}_{2} \mathrm{O}_{3} / \mathrm{SiO}_{2}$ または $\mathrm{TiO}_{2} / \mathrm{SiO}_{2}$ 比を増加させてもフラック スの熱物性が高合金鋼の連続鋳造に関する要件を引き続 き満たすことができる。非反応性 $\mathrm{CaO}-\mathrm{Al}_{2} \mathrm{O}_{3}$ 系モールドフ ラックスについては, 様々なフラックス材の添加を通じて 不均一な熱伝達を発生させる過度に高い結晶化温度やアス ペクト比の高い結晶化形態を回避することが特に肝要であ る。

現在の設計思想ではフラックスの潤滑能力と結晶化速度 を考慮しているが, 均一な熱伝達を実現するための結晶化 形態の制御はまだ完全には実現されていない。現在の知識 の多くは, 鋳造中の初期Cuspidine 結晶相で観察された初期 結晶化と典型的な均一結晶化に限定されているが, $\mathrm{CaO}-$ $\mathrm{Al}_{2} \mathrm{O}_{3}$ の初期結晶相の挙動はまだ完全に理解されていない。 急速に核生成するように見える Perovskite相は成長が制限 され, 過度の $\mathrm{TiO}_{2}$ 添加はフラックスの溶融温度を上昇させ る傾向があり，鋳造中の潤滑特性に有害である。そのため， Perovskite相の均一な成長を加速するための今後の試みは, その最終的な応用において重要になる。

さらに，フラックスにおける熱伝導率の役割はまだ明確 には明らかになっていない。最近の研究によると，フラッ クスの結晶化は一般的に輻射熱伝達を抑制しつつ伝導熱伝 達を大幅に増加させている。したがって，モールドフラッ

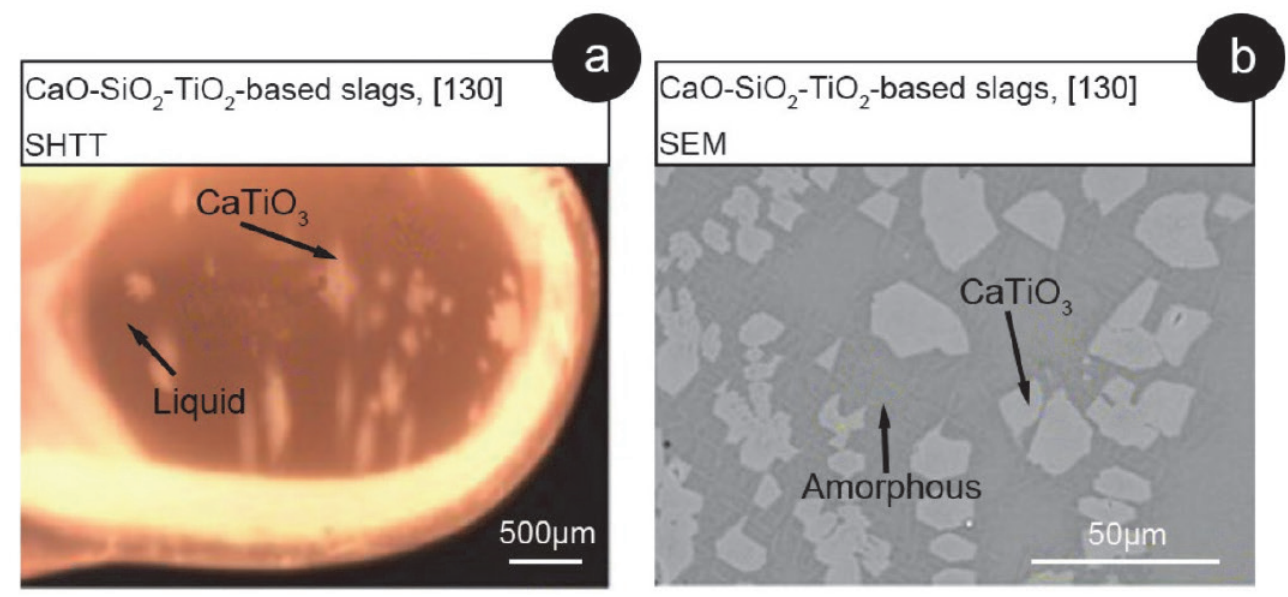

Fig. 6. (a) Morphology of perovskite obtained by SHTT and (b) morphology of perovskite obtained by SEM. Adapted from published literature. ${ }^{130)}$ (Online version in color.) 
クスを設計する際には, 輻射熱伝達と伝導熱伝達の観点か らの全熱流束を考慮する必要がある。さらに, 結晶化によ りフラックスの粘度が大幅に上昇する傾向があり, 潤滑 が失われる可能性もある。したがって, 高合金鋼の最適な モールドフラックスの開発には, 熱伝達メカニズムと潤滑 のバランスが依然として必要である。

広く検討されている流体の熱物理的特性に関して, 連続 鋳造用モールドフラックスは単一の液体状態ではなく, 通 常は水冷銅鋳型の鋳造長さにわたって固液共存状態とし て存在している。特に, 鋳造機の初期凝固では, フラック スがほとんど液体であると仮定できるが，鋳型の全長はメ ニスカスよりも遥かに長くなる。メニスカスから $300 \mathrm{~mm}$ を超えて広がる液体フラックスフィルムが確認されてい る ${ }^{131)}$ 。そのため, ほとんどのモールドフラックスベンダー は, モールドフラックスの break temperatureを適切に調ベ て提供するが, 詳細に検討すべきフラックス融体の固液非 ニュートン挙動を考慮して, 次世代の非反応性モールドフ ラックスを開発する必要がある。さらに，部分的にガラス 状のフラックスは，鋳型の全長に沿って高温に晒されると 結晶化して結晶相の割合が増加する可能性がある ${ }^{132)}$ 。こ の現象は，鋳型内の全体的な熱伝達に本質的に影響を与 え, これについても今後の研究で議論のテーマになると考 えられる。

\section{謝辞}

本研究は 2018 年にBK21プラスプロジェクトのDivision of Creative Materialsの第3段階による支援を受け, Competency Development Program for Industry Specialistsの一環として韓 国政府 (MOTIE) が出資している韓国産業技術振興院によ る助成金 (P0002019) の支援を受けた。

\section{文献}

1 ) S.He, Z.Li, Z.Chen, T.Wu and Q.Wang: Steel Res. Int., 90(2019), 1800424.

2 ) S.Martin, S.Richter, S.Decker, U.Martin, L.Krüger and D.Rafaja: Steel Res. Int., 82(2011), 1133.

3 ) A.Hamada and L.Karjalainen: Mater. Sci. Eng. A, 528(2011), 1819.

4 ) E.Zinngrebe, C.Van Hoek, H.Visser, A.Westendorp and I.Jung: ISIJ Int., 52(2012), 52.

5 ) G.Xu, X.Gan, G.Ma, F.Luo and H.Zou: Mater. Des., 31(2010), 2891.

6 ) M.Garibaldi, I.Ashcroft, M.Simonelli and R.Hague: Acta Mater, 110(2016), 207.

7 ) A.Fox, K.Mills, D.Lever, C.Bezerra, C.Valadares, I.Unamuno, J.Laraudogoitia and J.Gisby: ISIJ Int., 45(2005), 1051.

8 ) W.Wang, B.Lu and D.Xiao: Metall. Mater. Trans. B, 47(2016), 384.

9 ) H.Luo and H.Dong: Mater. Sci. Eng. A, 626(2015), 207.

10) K.C.Mills and A.B.Fox: ISIJ Int., 43(2003), 1479.

11) K.C.Mills: ISIJ Int., 56(2016), 14.

12) G.Kim, C.Kim and I.Sohn: ISIJ Int., 53(2013), 170.

13) S.S.Jung, G.H.Kim and I.Sohn: Trans. Indian Inst. Met., 66(2013), 577.

14) H.S.Park, H.Kim and I.Sohn: Metall. Mater. Trans. B, 42(2011), 324.

15) K.Mills, A.Fox, Z.Li and R.Thackray: Ironmaking Steelmaking,
32(2005), 26.

16) L.Zhang and W.Wang: Steelmaking, 33(2017), No.3, 20 (in Chinese).

17) Y.Kang, M.Kim, S.Lee, J.Cho, M.Park and H.Lee: Metall. Mater. Trans. B, 44(2013), 309.

18) M.Kim, S.Lee, J.Cho, M.Park, H.Lee and Y.Kang: Metall. Mater. Trans. B, 44(2013), 299.

19) T.Mukongo, P.Pistorius and A.Garbers-Craig: Ironmaking Steelmaking, 31(2004), 135.

20) R.Elliott, K.Coley, S.Mostaghel and M.Barati: JOM, 70(2018), 680.

21) E.M.Bellhouse, A.Mertens and J.R.McDermid: Mater. Sci. Eng. A, 463(2007), 147.

22) X.Fu, G.Wen, Q.Liu, P.Tang, J.Li and W.Li: Steel Res. Int., 86(2015), 110.

23) C.Ji, Y.Cui, Z.Zeng, Z.Tian, C.Zhao and G.Zhu: J. Iron Steel Res. Int., 22(2015), 53.

24) S.Lee, Y.Estrin and B.C.De Cooman: Metall. Mater. Trans. A, 45(2014), 717.

25) J.Yang and M.Zhu: ISIJ Int., 56(2016), 2191.

26) M.Kim, M.Park, S.Kang, J.Park and Y.Kang: ISIJ Int., 58(2018), 686.

27) Q.Wang, Y.J.Lu, S.P.He, K.C.Mills and Z.S.Li: Ironmaking Steelmaking, 38(2011), 297.

28) Z.Wang, Q.Shu and K.Chou: Steel Res. Int., 84(2013), 766.

29) J.Li, Q.Shu, X.Hou and K.Chou: ISIJ Int., 55(2015), 830.

30) E.Brandaleze, G.Di Gresia, L.Santini, A.Martín and E.Benavidez: Science and Technology of Casting Processes, Intech, Rijeka, (2012), 205.

31) K.Nagata and H.Fukuyama: Steel Res. Int., 74(2003), 31.

32) J.Y.Park, J.W.Ryu and I.Sohn: Metall. Mater. Trans. B, 45(2014), 1186.

33) A.I.Zaitsev, A.V.Leites, A.D.Lrtvina and B.M.Mogutnov: Steel Res., 65(1994), 368

34) M.Persson, S.Seetharaman and S.Seetharaman: ISIJ Int., 47(2007), 1711.

35) L.Zhou, W.Wang, B.Lu, G.Wen and J.Yang: Met. Mater. Int., 21(2015), 126.

36) J.Gao, G.Wen, Q.Liu, W.Tan and P.Tang: J. Non-Cryst. Solids, 409(2015), 8.

37) L.Zhou, W.Wang and K.Zhou: ISIJ Int., 55(2015), 1916.

38) W.Wang, D.Cai and L.Zhang: ISIJ Int., 58(2018), 1957.

39) J.Li, Q.Shu and K.Chou: Can. Metall. Q., 54(2015), 85.

40) J.Yang, J.Zhang, Y.Sasaki, O.Ostrovski, C.Zhang, D.Cai and Y.Kashiwaya: ISIJ Int., 56(2016), 574.

41) J.Cho, K.Blazek, M.Frazee, H.Yin, J.H.Park and S.Moon: ISIJ Int., 53(2013), 62.

42) G.H.Kim and I.Sohn: ISIJ Int., 52(2012), 68.

43) Q.Shu, Z.Wang, J.L.Klug, K.Chou and P.R.Scheller: Steel Res. Int., 84(2013), 1138.

44) C.Shi, M.Seo, H.Wang, J.Cho and S.Kim: Metall. Mater. Trans. B, 46(2015), 345

45) I.Sohn and D.J.Min: Steel Res. Int., 83(2012), 611.

46) L.Zhang, W.Wang, B.Zhai and I.Sohn: J. Am. Ceram. Soc., 103(2019), 112.

47) Y.Kang and K.Morita: ISIJ Int., 46(2006), 420.

48) J.H.Park, D.J.Min and H.S.Song: Metall. Mater. Trans. B, 35(2004), 269.

49) H.Kim, W.H.Kim, I.Sohn and D.J.Min: Steel Res. Int., 81(2010), 261. 50) G.Kim and I.Sohn: J. Am. Ceram. Soc., 102(2019), 6575.

51) L.Wang, Y.Cui, J.Yang, C.Zhang, D.Cai, J.Zhang, Y.Sasaki and O.Ostrovski: Steel Res. Int., 86(2015), 670.

52) H.Kim and I.Sohn: ISIJ Int., 51(2011), 1.

53) J.Li, Q.Shu and K.Chou: Ironmaking Steelmaking, 42(2015), 154.

54) G.H.Kim and I.Sohn: Metall. Mater. Trans. B, 45(2014), 86.

55) Z.Wang and I.Sohn: J. Am. Ceram. Soc., 101(2018), 4285. 
56) X.Huang, J.Liao, K.Zheng, H.Hu, F.Wang and Z.Zhang: Ironmaking Steelmaking, 41(2014), 67

57) X.Yu, G.Wen, P.Tang and H.Wang: Ironmaking Steelmaking, 36(2009), 623.

58) E.Gao, W.Wang and L.Zhang: J. Non-Cryst. Solids, 473(2017), 79.

59) T.Watanabe, H.Hashimoto, M.Hayashi and K.Nagata: ISIJ Int., 48(2008), 925

60) J.Wei, W.Wang, L.Zhou, D.Huang, H.Zhao and F.Ma: Metall. Mater Trans. B, 45(2014), 643.

61) J.Li, W.Wang, J.Wei, D.Huang and H.Matsuura: ISIJ Int., 52(2012), 2220.

62) L.Zhou, W.Wang and K.Zhou: Metall. Mater. Trans. E, 2(2015), 99.

63) M.D.Seo, C.B.Shi, J.W.Cho and S.H.Kim: Metall. Mater. Trans. B, 45(2014), 1874

64) Z.Wang and I.Sohn: Ceram. Int., 44(2018), 19268.

65) W.Yan, W.Chen, Y.Yang, C.Lippold and A.McLean: Ironmaking Steelmaking, 43(2016), 316.

66) W.Yan, W.Chen, Y.Yang, C.Lippold and A.McLean: Ironmaking Steelmaking, 42(2015), 698.

67) J.Gao, G.Wen, Q.Sun, P.Tang and Q.Liu: Metall. Mater. Trans. B, 46(2015), 1850.

68) Z.Zhang, G.Wen, J.Liao and S.Sridhar: Steel Res. Int., 81(2010), 516.

69) B.Lu and W.Wang: Metall. Mater. Trans. B, 46(2015), 852.

70) S.Ozawa and M.Susa: Ironmaking Steelmaking, 32(2005), 487.

71) S.Choi, D.Lee, D.Shin, S.Choi, J.Cho and J.Park: J. Non-Cryst. Solids, 345-346(2004), 157

72) M.Hayashi, R.A.Abas and S.Seetharaman: ISIJ Int., 44(2004), 691.

73) K.Nagata, M.Susa and K.S.Goto: Tetsu-to-Hagané, 69(1983), 1417 (in Japanese).

74) W.Yan, W.Chen, Y.Yang, C.Lippold and A.Mclean: ISIJ Int., 55(2015), 1000

75) W.Yan: Ph.D. thesis, University of Science and Technology Beijing, (2016), http://cdmd.cnki.com.cn/Article/CDMD-10008-1016044564. htm, (accessed 2015-12-21).

76) H.Wang, P.Tang and G.H.Wen: J. Univ. Sci. Technol. Beijing, 33(2011), 544

77) H.Wang, P.Tang, G.Wen and X.Yu: Ironmaking Steelmaking, 38(2011), 369

78) W.Wang, X.Yan, L.Zhou, S.Xie and D.Huang: Metall. Mater. Trans. $B, 47(2016), 963$.

79) Z.Hao, W.Chen and C.Lippold: Metall. Mater. Trans. B, 41(2010), 805 .

80) L.Zhou, W.Wang, J.Wei and B.Lu: ISIJ Int., 53(2013), 665.

81) B.Lu, W.Wang, J.Li, H.Zhao and D.Huang: Metall. Mater. Trans. B, 44(2013), 365

82) W.Yan, W.Chen, Y.Yang, C.Lippold and A.McLean: Steel Res. Int., 87(2016), 173

83) L.Zhou, W.Wang and K.Zhou: Metals, 6(2016), 139.

84) H.Zhao, W.Wang, L.Zhou, B.Lu and Y.Kang: Metall. Mater. Trans. B, 45(2014), 1510

85) L.Zhang, W.Wang and H.Shao: J. Iron Steel Res. Int., 26(2019), 336.

86) K.Blazek, H.Yin, G.Skoczylas, M.McClymonds and M.Frazee: AIST Trans., 8(2011), 232

87) J.Liao, Y.Zhang, S.Sridhar, X.Wang and Z.Zhang: ISIJ Int., 52(2012), 753.

88) Z.Zhang, G.Wen, P.Tang and S.Sridhar: ISIJ Int., 48(2008), 739.

89) G.Zhang, Y.Zhen and K.Chou: J. Iron Steel Res. Int., 23(2016), 633.

90) Z.Wang and I.Sohn: J. Am. Ceram. Soc., 102(2019), 5632.

91) L.Wang, C.Zhang, D.Cai, J.Zhang, Y.Sasaki and O.Ostrovski: Metall. Mater. Trans. B, 48(2017), 516.

92) L.Wang, J.Zhang, Y.Sasaki, O.Ostrovski, C.Zhang and D.Cai: Metall. Mater. Trans. B, 48(2017), 1055

93) Q.Wang, J.Yang, C.Zhang, D.Cai, J.Zhang and O.Ostrovski: J. Iron Steel Res. Int., 26(2019), 374.

94) T.Wu, Q.Wang, S.He, J.Xu, X.Long and Y.Lu: Steel Res. Int.,
83(2012), 1194

95) S.Sukenaga, N.Saito, K.Kawakami and K.Nakashima: ISIJ Int., 46(2006), 352

96) J.Yang, J.Zhang, Y.Sasaki, O.Ostrovski, C.Zhang, D.Cai and Y.Kashiwaya: Metall. Mater. Trans. B, 48(2017), 2077.

97) C.Yang, G.Wen and P.Tang: Steel Res. Int., 87(2016), 880 .

98) B.Lu, K.Chen, W.Wang and B.Jiang: Metall. Mater. Trans. B, 45(2014), 1496

99) H.Liu, G.Wen and P.Tang: ISIJ Int., 49(2009), 843

100) B.Jiang, W.Wang, I.Sohn, J.Wei, L.Zhou and B.Lu: Metall. Mater. Trans. B, 45(2014), 1057

101) L.Zhou, H.Li, W.Wang, D.Xiao, L.Zhang and J.Yu: Metall. Mater. Trans. B, 49(2018), 2232

102) D.Xiao, W.Wang and B.Lu: Metall. Mater. Trans. B, 46(2015), 873.

103)F.Dong, Y.Wang and B.Wang: Special Steel, 27(2006), No.6, 7 (in Chinese).

104) Z.Li, X.You, M.Li, Q.Wang, S.He and Q.Wang: Metals, 9(2019), 142.

105) L.Zhou, H.Li, W.Wang, Z.Wu, J.Yu and S.Xie: Metall. Mater. Trans. $B, \mathbf{4 8}(2017), 2949$.

106) J.Park, G.H.Kim, J.B.Kim, S.Park and I.Sohn: Metall. Mater. Trans. $B, 47(2016), 2582$

107) J.Park and I.Sohn: Int. J. Heat Mass Transf., 109(2017), 1014.

108) T.Watanabe, H.Fukuyama and K.Nagata: ISIJ Int., 42(2002), 489.

109) D.J.Kim and J.H.Park: Metall. Mater. Trans. B, 43(2012), 875.

110) Q.Wang, S.Qiu and P.Zhao: Metall. Mater. Trans. B, 43(2012), 424

111) L.Zhang, W.Wang, S.Xie, K.Zhang and I.Sohn: J. Non-Cryst. Solids, 460(2017), 113 .

112) S.He, Q.Wang, J.Zeng, M.Zhang and B.Xie: J. Iron Steel Res., 12(2009), 59 .

113) M.Kim and Y.Kang: Calphad, 61(2018), 105.

114) X.Yu, G.Wen, P.Tang, F.Ma and H.Wang: J. Iron Steel Res. Int., 18(2011), 20.

115) W.Yan, W.Chen, L.Carsten and H.Zheng: Special Steel, 34(2013), No.1, 45 (in Chinese).

116) T.Hiromoto, T.Shima and R.Sato: 62nd Steelmaking Conf. Proc., Iron and Steel Society, Warrendale, PA, (1979), 40.

117) X.Qiu, B.Xie, X.Qing, J.Diao, Q.Huang and S.Wang: J. Iron Steel Res. Int., 20(2013), 27.

118) J.Diao, B.Xie, N.Wang, S.He, Y.Li and F.Qi: ISIJ Int., 47(2007), 1294

119) J.Cho, S.Yoo, M.Park, J.Park and K.Moon: Metall. Mater. Trans. B, 48(2017), 187

120) Z.Wang, Q.Shu, X.Hou and K.Chou: Ironmaking Steelmaking, 39(2012), 210

121) L.Sun, H.Wang, M.Jiang, Q.Lin, C.Liu and Y.Zou: Adv. Mater. Res., 189-193(2011), 107.

122) K.Zheng, Z.T.Zhang, L.L.Liu and X.D.Wang: Metall. Mater. Trans. $B, \mathbf{4 5}(2014), 1389$

123) H.Park, J.Y.Park, G.H.Kim and I.Sohn: Steel Res. Int., 83(2012), 150.

124) C.Feng, M.Chu, J.Tang, J.Qin, F.Li and Z.Liu: Int. J. Miner. Metall. Mater, 23(2016), 868.

125) G.Wen, S.Sridhar, P.Tang, X.Qi and Y.Liu: ISIJ Int., 47(2007), 1117.

126) S.He, X.Long, J.Xu, T.Wu and Q.Wang: Ironmaking Steelmaking, 39(2012), 593

127) H.Nakada and K.Nagata: ISIJ Int., 46(2006), 441

128) Z.Wang, Q.Shu and K.Chou: Metall. Mater. Trans. B, 44(2013), 606.

129) X.Qi, G.Wen and P.Tang: J. Non-Cryst. Solids, 354(2008), 5444.

130) D.Zheng, J.Li, C.Shi and J.Ju: Ironmaking Steelmaking, 45(2018), 135.

131) P.Hu, X.Wang, J.Wei, M.Yao and Q.Guo: ISIJ Int., 58(2018), 892.

132) C.Yang, G.Wen, Q.Sun and P.Tang: Metall. Mater. Trans. B, 48(2017), 1292. 